\title{
EL PATRIMONIO EN LA IMAGEN TURÍSTICA INDUCIDA DE ANDALUCÍA
}

\author{
José David Albarrán Periáñez* \\ Universidad Complutense de Madrid \\ https://orcid.org/0000-0002-4774-9639 \\ Manuel de la Calle Vaquero* \\ Universidad Complutense de Madrid \\ https://orcid.org/0000-0002-9594-7373
}

\section{RESUMEN}

El turismo es un sector eminentemente visual, lo que favorece que los destinos trabajen en la generación de representaciones seductoras con las que atraer a los potenciales visitantes. En este trabajo se analiza el modo en que el patrimonio ha sido incorporado a la construcción de la imagen inducida andaluza en las últimas décadas, llevándose a cabo un análisis semiótico de las representaciones proyectadas en el material promocional. A través del mismo se constata la idea de que dicha imagen es herencia de la identidad universal de la región construida durante el Romanticismo, en la que imperan los elementos propios de su pasado árabe, determinándose que territorios que cuentan con una imagen universal consolidada, en la que el patrimonio ejerce un papel fundamental, se valen de ésta para la formación de su imagen inducida por su fácil reconocimiento internacional.

Palabras clave: Imagen turística; Imagen inducida; Patrimonio; Promoción turística; Andalucía.

\section{Heritage in the induced tourism image of Andalusia}

\section{ABSTRACT}

Tourism is an eminently visual sector, which encourages destinations to work on generating seductive representations to attract potential visitors. This paper analyses how heritage has been incorporated into the construction of the Andalusian induced image in recent deca-

Fecha de recepción: 22 de diciembre de 2020.

Fecha de aceptación: 21 de junio de 2021.

*Departamento de Geografía. Facultad de Geografía e Historia. Universidad Complutense de Madrid. Edif. B. Calle del Profesor Aranguren, s/n. 28040 MADRID (España).E-mail: josedalb@ucm.es, mcalleva@ghis.ucm.es 
des, developing a semiotic analysis of the representations projected in the promotional material. Through this, it emerges that this image is the inheritance of the universal identity of the region built during Romanticism, in which the elements of its Arab past prevail. Finally, the study provides that territories that have a consolidated universal image, in which heritage plays a fundamental role, they use it to form their induced image due to its easy international recognition.

Keywords: Tourism image; Induced image; Heritage; Tourism promotion; Andalusia

\section{INTRODUCCIÓN}

En un contexto global marcado por la consolidación de la industria turística como uno de los sectores más importantes de la economía, los destinos compiten, en palabras de San Martín, Rodríguez y Vázquez (2006:70), "sobre la base de su imagen percibida en relación con los destinos competidores". Así, la relevancia que tiene el concepto de la imagen turística para la promoción y comercialización de los destinos ha favorecido que ésta adquiera notable atención en el marco de la investigación en turismo (Batista et al., 2020). Existe, de hecho, cierto consenso en la idea de que la imagen turística de un destino es un factor crucial en el proceso de elección del mismo (Goodrich, 1978; Woodside y Lysonski, 1989; Andreu et al., 2000; Perelló, 2006; Edelheim, 2007; San Martín y Rodríguez, 2008; Picón et al., 2013; Castro y Rodrigues, 2017), condicionado en gran medida por la representación que es proyectada por los responsables de la promoción del propio destino (Alvarado-Sizzo et al., 2018). Es por ello que estos agentes se enfrentan a un doble reto: conformar imágenes positivas que induzcan al viaje, al tiempo que los diferencien de otros lugares (Novo et al., 2013). Así, la función de estos organismos es la de producir una identidad singular y competitiva, capaz de alcanzar una posición destacada en las percepciones de los consumidores y tener éxito en el mercado contemporáneo (Santos, 2008), cada vez más especializado y competitivo.

Las semánticas visuales que caracterizan la imagen proyectada de cualquier destino turístico actúan de este modo como autodescripciones del lugar, pues a través de ellas los organismos encargados de la promoción turística local seleccionan ciertos elementos en forma de reclamo, que permiten al destino ser reconocido por los consumidores (Rodríguez et al., 2012; Novo et al., 2013). Los bienes patrimoniales se convierten así en recursos clave de diferenciación (Castro y Rodrigues, 2017), a través de cuya proyección se garantiza la difusión de una imagen particular y única de cada territorio, pues estos bienes suponen iconos a los que ha sido atribuido un especial reconocimiento a lo largo de la historia. Sin embargo, la simplificación que conlleva la creación de la imagen de un destino turístico puede llegar a generar ciertos estereotipos y reiteraciones de elementos aislados, en gran medida debido a la influencia que las imágenes gestadas durante el Romanticismo, con el inicio de los viajes interestatales en Europa, tienen sobre aquellas.

Estas formas de representación estereotipadas chocan, no obstante, con los planteamientos más contemporáneos del patrimonio en clave territorial (Ortega, 1998; Troitiño, 
1998, 2000, 2011; Castrillo y Tremiño, 1998; Feria, 2010, 2013; Mulero, 2015; Troitiño y Troitiño, 2015), pues éstos exigen pasar de una perspectiva monumental a una óptica más espacial. Así, aunque en las últimas décadas se han hecho importantes esfuerzos por diversificar las imágenes turísticas de los destinos, es necesario analizar si esta evolución tiene correlación con la producida en el ámbito patrimonial. El surgimiento de nuevos segmentos turísticos, la irrupción de los entornos virtuales, o la necesidad de reafirmar la presencia en el destino por parte de los turistas no han hecho más que reforzar los estereotipos en la medida en que los iconos más representativos de cada destino en el imaginario global son reiteradamente fotografiados y perpetuados (Santos, 2008), dando lugar al denominado "círculo de las representaciones" concebido por Hall (1997).

En este sentido, la presente investigación atiende al estudio del patrimonio en las representaciones que han sido proyectadas por las instituciones con competencias en promoción turística en uno de los destinos turísticos más icónicos del mundo por la potencia estética y el exotismo asociado a su patrimonio a lo largo de los últimos siglos: la Comunidad Autónoma de Andalucía. Y es que Andalucía es una de las regiones con mayor riqueza patrimonial y una de las más visitadas de Europa, siendo la comunidad autónoma con más conjuntos históricos declarados de España (Ministerio de Cultura y Deporte, 2019) y la que mayor superficie de espacios naturales protegidos y número de éstos posee (Ministerio para la Transición Ecológica, 2019). Es, además, la región española con mayor número de bienes inscritos en la Lista de Patrimonio Mundial de UNESCO, y la comunidad donde se hallan algunos de los monumentos más visitados del país, o la que más establecimientos hoteleros concentra (INE, 2019a). En 2019 fue, a su vez, la cuarta región con más visitas internacionales y una en las que el gasto turístico fue más elevado (INE, 2019b; INE, 2019c), en un contexto nacional que se había consolidado antes de la irrupción de la pandemia por Civid-19 como el segundo destino turístico más visitado del mundo y el segundo en volumen de ingresos (Banco Mundial, 2019). Sin embargo, si algo resulta llamativo en esta región es que, a nivel turístico, este legado ha favorecido que su identidad haya llegado a constituirse como sinónimo de todo lo español, con la construcción de una iconografía que ha situado a la andaluza como una de las regiones más reconocidas del mundo en el imaginario colectivo global.

La construcción de esta identidad se ha llevado a cabo por medio de una serie de elementos y símbolos que, a manera de acervo iconográfico, se han consolidado como atributos propios del territorio por medio de un discurso que se ha trasmitido generalmente de manera visual. Así, estos atributos frecuentemente responden a elementos concretos del patrimonio cultural y natural de la región, habiéndose consolidado éstos como componente central de la promoción turística desarrollada por la administración regional hasta nuestros días. Es por ello que, con objeto de lograr un desarrollo turístico más sostenible y ordenado, se hace necesario llevar a cabo un análisis que eluda los datos meramente económicos para avanzar en planteamientos en los que el turismo, entendido como actividad con un fuerte poder transformador a nivel espacial, atienda a una concepción del lugar más holística, trasversal y veraz.

De esta forma, en el presente trabajo se analizan los procesos de selección y uso del patrimonio en la construcción de las imágenes turísticas inducidas llevadas a cabo por parte del gobierno andaluz. Tras una primera parte enfocada en el estudio teórico de la materia, y un posterior apartado dedicado a la presentación de la metodología aplicada, 
esta investigación desarrolla un análisis de la imagen promocional editada durante las últimas décadas en Andalucía. Para ello se lleva a cabo un análisis semiótico aplicado a los soportes visuales editados por los agentes públicos responsables de la promoción a escala regional en democracia. Finalmente se dedica un apartado al desarrollo de la discusión de resultados y otro a exponer las conclusiones.

\section{MARCO CONCEPTUAL}

Durante las últimas décadas han sido numerosos los trabajos elaborados desde múltiples disciplinas sobre el concepto de la imagen en el marco de los estudios sobre la percepción del entorno. De éstos se desprenden definiciones que, en suma, atienden a percepciones, ideas y creencias imprescindibles para que un individuo o grupo de individuos organice y procese los estímulos recibidos a diario, dotando de sentido al entorno y la realidad (Dowling, 1986; Gartner, 1989; Barrio et al., 2009). Es por ello que, para Baloglu y McCleary (1999), el mundo no es más que una percepción o representación psicológica de la realidad que reside en la mente de los humanos, que son capaces de reproducir en su mente representaciones simuladas del mundo real, incluso de territorios que no han visitado (Alvarado-Sizzo et al., 2018), debido a la existencia de una relación inherente entre la imagen de referencia - por ejemplo una fotografía- y su referente real. Este hecho permitiría "creer en la realidad de esta representación como una transcripción objetiva de la misma" (Markwick, 2001:422).

Dentro de esta abundante producción académica existe cierto consenso sobre la idea de que cada persona posee una imagen particular y única sobre un determinado territorio, pudiendo un mismo lugar tener tantas imágenes como individuos reflexionen sobre él, pues diversos autores defienden que son las variables sociológicas del sujeto las que contribuyen a seleccionar unos determinados aspectos u otros (Baloglu y McCleary, 1999; Traverso, 2007; Traverso y Román, 2009). En paralelo, a lo largo de las últimas décadas otros académicos han tratado de demostrar la influencia de los contextos sociales en la generación de esta imagen, evidenciando que personas pertenecientes a distintos grupos sociales o regiones geográficas disponen de percepciones muy homogéneas sobre un mismo espacio, interviniendo en este proceso factores culturales, sociodemográficos o de distancia (Richardson y Crompton, 1988; San Martín, 2005; Berger y Luckmann, 1986; Hiernaux, 2002). En este sentido, el imaginario social ocupará un rol preponderante en la configuración de las imágenes de los territorios al ser éstas producidas en contextos cultural e históricamente conformados (Morgan y Pritchard, 2001) a través de una matriz de conexiones entre diferentes ideas, imágenes, sentimientos, creencias y proyectos de la experiencia colectiva de los individuos (Gamero, 2007). Por tanto, la imagen de un lugar percibida por el sujeto estará fundamentada en un conjunto dominante de ideas y creencias construidas sobre la propia realidad (Hernández, 2008).

En 1965, en un contexto caracterizado por la irrupción del marketing turístico, la generación de marcas de destino o la creación de estrategias de posicionamiento, Reynols iniciaría el estudio de la imagen turística al aplicar estos conceptos al ámbito del turismo. Con ello, el autor trataría de explicar el proceso de formación de la imagen como el desarrollo de un concepto mental sobre la base de un reducido número de impresiones que 
resultan seleccionadas de entre un conjunto mucho más amplio (Reynols, 1965). Durante las décadas siguientes, términos como impresión (Gartner y Hunt, 1987; Milman y Pizam, 1995; Pritchard y Morgan, 2001), percepción (Richardson y Crompton, 1988; Echtner y Ritchie, 1991; Tapachai y Waryszak, 2000) o conjunto de creencias, ideas o emociones (Chon, 1991; Hiernaux, 2002; Kim y Richardson, 2003) han sido constantemente usados para la definición del concepto. Así, una de las acepciones más ampliamente utilizadas es la formulada por Crompton (1979), que afirma que la imagen de un destino turístico es la suma de creencias, ideas e impresiones que una persona tiene sobre el mismo.

El concepto ha sido categorizado como subjetivo, individual y cambiante por la mayor parte de autores con trabajos en la materia, quienes consideran la existencia de ciertas diferencias entre la imagen percibida del destino y su realidad objetiva (Pearce, 1988; Bigné et al., 2001;Kim y Richardson, 2003; San Martín et al., 2006; San Martín y Rodríguez, 2008; Camprubí, 2011; Moreno et al., 2012; Rodríguez et al., 2012; McDonald, 2015), de la que aquella será una simplificación compleja en la mente de los individuos a partir de determinados atributos o características individuales (Gartner, 1989, 1993). En la selección de dichos atributos, distintos estudios defienden la influencia de factores que pueden ser agrupados de manera general en dos grupos: factores internos y factores externos (Baloglu y McCleary, 1999; Hung et al., 2012). Los primeros se refieren a las circunstancias psicológicas y las características sociodemográficas del perceptor, como la edad, la educación, o la distancia social (Um y Crompton, 1990; Baloglu y McCleary, 1999; Camprubí, 2011);mientras que los segundos suponen las fuentes de información consultadas (Frias et al., 2008), así como la experiencia previa del sujeto.

Estos autores, además, diferencian entre dos tipos de imagen de un destino turístico: aquellas que son percibidas por los individuos y las que son proyectadas sobre el propio destino (Gunn, 1988; Galí y Donaire, 2005). Para autores como Baloglu y McCleary (1999), la imagen percibida supone un concepto formado por tres componentes interrelacionados básicos: cognitivo, afectivo y conativo; donde el primero se define como la suma de lo que sabe el individuo sobre un destino; el afectivo hace alusión a los sentimientos, motivaciones y deseos ante el mismo (Gartner, 1994); y el conativo, resultado de los anteriores, se refiere a la adecuación a unas circunstancias concretas, a la probabilidad de visita (Pike y Ryan citado por Andrade, 2011) o la predisposición a la misma (ÁlvarezSouza, 2015). Por su parte, atendiendo al componente emocional de la imagen, Echtner y Ritchie $(1991,1993)$ establecen la existencia de tres continuos bipolares en la definición de la imagen percibida: atributo-holístico, que se fundamenta en una contraposición entre la selección de atributos individuales del destino y aspectos más holísticos de representación del mismo; funcional-psicológico, que discierne entre las características del destino que son directamente observables por el turista y aquellas que resultan más intangibles, abstractas y difíciles de medir; y común-único, que se basa en la distinción entre aquellas características comunes a distintos lugares, ya sean de carácter funcional o psicológico, y aquellas que se perciben como únicas para cada destino. Así, para Bigné, Sánchez y Sánchez (2001), el componente único conlleva importantes implicaciones estratégicas al configurarse como una auténtica fuente de diferenciación y ventaja competitiva del destino turístico, siendo éste el de mayor preeminencia en la construcción de las imágenes turísticas proyectadas de los lugares. 
Estas imágenes proyectadas, por su parte, consideradas de manera general como un importante factor de atracción en el proceso de elección del destino (Andreu et al., 2000; Novo et al., 2013), han sido categorizadas por diversos autores como orgánicas e inducidas (Gunn, 1988; Perelló, 2006). Las primeras estarán formadas por fuentes de información que no están directamente asociadas a la promoción del destino, mientras que las segundas son creadas a través de las estrategias de marketing del mismo, y representan el primer contacto real entre los destinos turísticos y los turistas potenciales (Martín, 2003). Gunn (1988), adicionalmente, hace una diferenciación entre las primeras, afirmando que además de las imágenes inducidas existen las denominadas universales, que se corresponden con esos productos históricos instalados en el imaginario social con gran solidez por un largo periodo de tiempo, y las efímeras, que representan las imágenes que son conformadas de manera inconsciente y que hacen alusión a hechos o noticias que ponen en valor de forma transitoria un determinado elemento, es decir, la promoción que se escapa al control de las organizaciones encargadas de la proyección de los destinos -periódicos, documentales, reportajes, etc. Posteriormente, Gartner (1994), basándose en las propuestas de Gunn, diferenciaría entre cuatro tipos de agentes encargados de proyectar esta información: agentes inductivos, agentes inductivos encubiertos, agentes autónomos y agentes orgánicos ${ }^{1}$. Así, mientras los dos últimos contribuyen a la formación de las imágenes universales, los agentes inductivos harán lo propio con las imágenes inducidas (Camprubí et al., 2009).

Las percepciones que poseen los individuos sobre los diferentes territorios, conformadas en contextos culturalmente definidos, serán, por tanto, influidas o reforzadas, entre otros, por los agentes involucrados en la configuración de la imagen promocional de los destinos, quienes, a través de la imagen inducida, suscitan el interés por viajar y determinan, en última instancia, cuáles son los elementos que se convertirán en fundamentales para visitar, mirar o fotografiar (Urry, 1990). Estos planteamientos se basan en la idea de que el turismo es una industria experiencial e inequívocamente visual (ibid.), en la que la imagen, en cuya configuración intervienen multitud de agentes, afecta a los comportamientos turísticos.

Estas teorías dan lugar a una definición de la imagen turística que responde a las diferentes etapas de la experiencia turística (Cohen, 1979), existiendo un gran consenso académico sobre la influencia que ésta ejerce en la decisión y el comportamiento de los turistas durante las mismas (Hunt, 1975; Umy Crompton, 1990; Dann, 1996; Urry, 1996; Baloglu y McCleary, 1999; Markwich, 2001; Alvarado-Sizzo et al., 2018). Así, en primer lugar, autores como Echtner y Ritchie (1991) destacan el papel de la imagen en la elección del destino, consolidándose durante la globalización neoliberal de mediados del siglo XX la idea de que cuando dichas imágenes son percibidas como atractivas por los potenciales

1 Overt Induced I, agentes promotores del destino; Overt Induced II, turoperadores y otros agentes implicados en la difusión de los valores del destino; Covert Induced I, celebridades y medios que captan la atención de las masas; Covert Induced II, artículos, reportajes o historias sobre el destino procedentes de una fuente sin aparente interés en el desarrollo del mismo; Autonomous, reportajes, películas o documentales que representan la interpretación de un agente independiente sobre el destino; Unsolicited Organic, información recibida por parte de individuos que han estado en el área y que no ha sido solicitada; Solicited Organic, cuando la predisposición a ir al destino es alta y se solicita información a fuentes sobre el mismo, como amigos o familiares (Gartner, 1994). 
visitantes, éstas actúan como un factor fuertemente influyente en el proceso de toma de decisiones en la planificación del viaje (Goodrich, 1978; Woodside y Lysonski, 1989; Andreu et al., 2000; Perelló, 2006; Edelheim, 2007; San Martín y Rodríguez, 2008; Picón et al., 2013; Castro y Rodrigues, 2017). Posteriormente, una vez en el destino, la satisfacción del visitante dependerá en gran medida de la comparación entre su percepción en ese momento y las expectativas basadas en la experiencia previa, ligadas al imaginario social y la publicidad, lo que conlleva que la complacencia del visitante en el territorio requiera de convergencia entre las imágenes emitidas y las recibidas en el lugar de la visita, es decir, entre la imagen ofertada y la realidad que se encuentra (Ashworth, 1990). Realizado el viaje, el turista desarrollará cierta lealtad hacia el destino a través de un proceso en el que proyectará una imagen compleja del mismo, suma de la imagen percibida anteriormente y la experiencia en el lugar, que expondrá como reafirmación de lo vivido ante los demás (Suvantola citado por Camprubí et al., 2009). Esto es lo que Galí y Donaire (2006) definen como imágenes a priori, conformadas antes de la realización del viaje; in situ, producidas con el desplazamiento al destino, donde el individuo pretende confirmar la existencia de los elementos que le han sido descritos previamente; ya posteriori, tras el regreso y con la constatación de la existencia de dichos bienes, suponiendo la reinterpretación o reconstrucción de la experiencia vivida una vez ha concluido el viaje.

El impacto de la imagen proyectada por el destino es mayor cuanto más congruencia existe entre ésta y las motivaciones del turista (Perelló, 2006). Sobre esta idea, Gartner (1993) plantea que la realidad objetiva del destino no es necesariamente el factor determinante de su elección, sino que es la imagen percibida por el individuo lo que determina qué destinos permanecen y cuáles son eliminados de cualquier consideración. Teniendo en cuenta el modelo del comportamiento del turista propuesto por Chon (1991) podemos concluir que el papel que ejercen los organismos encargados de dar forma a la imagen promocional desde el propio destino es fundamental, pues, según el autor, tras una inicial motivación por viajar el turista inaugura una etapa de búsqueda de información sobre el destino, reparando en la imagen inducida del mismo, tras la cual lleva a cabo la definitiva elección del viaje.

Así, para Berno y Ward (2005), la simbólica es una de las tres dimensiones cuya transformación conlleva el desarrollo turístico de un territorio, además de la reinvención del propio espacio, a través de un proceso que involucra su adaptación física, y su adecuación funcional, con el acondicionamiento de un modelo organizacional efectivo. Dicha dimensión supondría la creación de una imagen fortalecida en el contexto del marketing turístico, por lo que la imagen turística representaría un método de difusión del discurso institucional. Tal discurso se fundamenta, por ende, en la forma en que el propio territorio quiere ser visto (García y Mercado, 2019), estando basado en la mercantilización de las singularidades territoriales y la apelación a aspectos emotivos (Troncoso, 2013) y ventajas competitivas (Novo et al., 2013). La imagen turística se convierte de este modo en una representación figurada de la realidad, una construcción de acuerdo a los intereses de los organismos encargados de transmitir el discurso, que juegan un papel esencial en la configuración de la identidad del territorio al comercializar el mismo como destino a través de una promoción que es vital para su diferenciación en el mercado actual (Britton, 1990). 
Este concepto de diferenciación bajo el que tienen a establecerse las imágenes de los destinos está relacionado directamente con la alteración de los cánones tradicionales de los territorios en pro de alcanzar una imagen más atractiva para los potenciales visitantes (Edelheim, 2007), adulterando sus cualidades hasta hacerlas turísticamente rentables (Martín, 2003). En consecuencia, y debido a que a día de hoy la mayor parte del territorio global ha sido transformada por la acción humana y lugares muy distantes pueden llegar a presentar similitudes muy precisas bajo la influencia de la globalización (Maderuelo, 2006), los territorios tratan de destacar en un contexto, según Barthes (1957), caracterizado por la pervivencia de la estética decimonónica. De esta forma, la imagen turística proyectada por las instituciones de muchos territorios se fundamenta en la configuración de una imagen sintetizada de los mismos que responde a la pervivencia de la iconografía decimonónica hasta nuestros días (Lerivray, 1975; Torres, 2017; Méndez, 2017), un hecho especialmente manifiesto en algunos de los grandes destinos turísticos del Mediterráneo. Esto ha supuesto un continuo proceso de conformación que se inicia con el análisis de los sistemas territoriales durante la Ilustración (Barke y Towner, 1996), cuando se confiere una importancia trascendental a la literatura que narra las experiencias de los viajeros por lugares remotos (Guerrero, 1990; Álvarez-Souza, 2015), y termina por configurar el imaginario colectivo global a partir de imágenes que pueden ser reales o poéticas (Hiernaux, 2002).

De este modo, a día de hoy los visitantes siguen centrando su atención en un número muy limitado de bienes y espacios, transitando por los mismos lugares, y visitando los mismos recursos que a principios de siglo $\mathrm{XX}$, cuando el turismo solo era practicado por las clases sociales pudientes (Troitiño y Troitiño, 2011). Estos recursos son aquellos que encarnan la identidad turística que se ha venido proyectando de cada territorio (Brandis, 2009), puesto que la perspectiva romántica ha terminado por generar una imagen canónica y particular de los destinos (Lagunas, 2005) que se ha visto reforzada en las últimas décadas por la promoción a gran escala (McDonald, 2015). Este hecho ha favorecido la construcción de imágenes que enaltecen ciertos elementos y espacios patrimoniales que poseen un fuerte vínculo con las representaciones de raíz decimonónica, remitiendo a lo remoto y prístino en una (re)creación de los mismos (Alvarado-Sizzo et al., 2018). De este modo, se induce al turista a viajar no sólo espacialmente, sino también a través del tiempo, para entrar en un territorio donde impera la autenticidad y la pureza de un espacio exótico imaginado durante décadas por la sociedad occidental, pero que obvia elementos de la realidad que puedan alterar el discurso original. Así, para Galí y Donaire (2005), la mayoría de lugares del mundo globalizado son "prisioneros" de sus propias imágenes, llegando incluso a ser acondicionados con objeto de ajustarse a los deseos preferentes de la demanda.

Esta selección parte, por tanto, de la Ilustración y el Romanticismo, una época caracterizada por el ansia de conocimiento, que es perseguido a partir de la observación directa que permite el viaje (Chaves, 2012). Con la consolidación de los libros en los que se describen estos periplos se consolidará también la incorporación de elementos que tratan de suscitar placer o emociones en el lector (Bernal, 1985; Berger y Luckmann, 1986; Guerrero, 1990; Poulet, 1995). Sin embargo, en muchas ocasiones, este deseo de causar impacto favorecerá que el contenido de estos libros no se corresponda del todo con la realidad que describen, apareciendo durante todo el Romanticismo relatos imaginarios que se fundamentan en clichés y prejuicios generalizados, persiguiendo recordar lo meramente 
pintoresco, lo susceptible de generar emoción (Carrère-Lara, 2001) y otorgar al lugar una dimensión de misticismo y divinidad. Más adelante, este fenómeno se extendería a través de las guías de viaje posteriores, criticadas por Barthes en su ensayo Mitologías, en el que afirmaba que en ellas "la selección de los monumentos suprime la realidad de la tierra y de los hombres, no testimonia nada del presente, es decir histórico; por eso, el monumento se vuelve indescifrable, por lo tanto estúpido" (Barthes, 1957:126). Así, muchas guías se centrarían en mostrar de manera aislada ciertos bienes y espacios, contribuyendo a la configuración del "estereotipo del destino" intrínseco a la definición de la imagen turística llevada a cabo por Pearce (1988). Este sería el caso de la guía editada por Murray en 1844 A Handbook for Travellers in Spain and Readers at Home, un trabajo de Richard Ford sobre España con información de distancias, caminos, excursiones o edificios emblemáticos que fue completada dos años más tarde con Gathering from Spain, donde se incorporaban nada menos que 104 comparaciones entre España y Oriente (López, 2001).

El caso español es, de hecho, uno de los más representativos de la construcción de una imagen en base a las aportaciones de agentes ajenos al territorio entre los siglos XVII y XIX, siendo abundante la literatura existente sobre el país desde el comienzo de los viajes interestatales. En este contexto, además, destacará el territorio andaluz, ya que, de acuerdo a lo expuesto por López (2001), de los 599 relatos de viajes sobre España que contabiliza la bibliografía de viajes de Foulché-Delbosc en el siglo XIX, 318 se refieren a la región andaluza. Ésta suponía uno de los territorios más opuestos a los cánones europeos en términos de cultura y paisaje, por distancia y persistencia de un pasado árabe cada vez más valorado en el exterior. Y sería precisamente la normalización de esta diferencia respecto al resto de Europa por parte de la corriente romántica la que se consolidaría en el tópico turístico que ha pervivido hasta hoy (Lasso, 2006; Hernández, 2007, 2008). Un hecho éste que se ha visto favorecido, además, por la sobreestimación y manipulación de la imagen andaluza durante el franquismo (Puche, 2019; Albarrán, 2021), que la mantendría como representación de todo un país proyectado como "preservador sólido de la autenticidad de su cultura" (Fodor, 1952) en plena efervescencia costumbrista.

De este modo, la literatura y los trabajos gráficos producidos durante la Edad Moderna han influido de forma notable en el comportamiento de los viajeros en tierras andaluzas, así como en la imagen que tanto éstos como las instituciones oficiales han proyectado sobre la región (Álvarez-Souza, 2015), siendo incuestionable que la imagen generada durante este periodo sigue estando presente en la promoción turística oficial. En un estudio que trataba de averiguar cuáles eran los clichés de España entre los ciudadanos extranjeros en el año 2000, Turespaña determinó que la imagen genérica percibida del país se basaba en tres elementos principales -el buen tiempo, el sol y la playa; la tradición y el folclore; y el carácter español- (Noya citado por Fuentes, 2005), siendo éstos los mismos sobre los que de manera general se ha articulado el discurso proyectado por los agentes responsables de la promoción turística estatal.

En la actualidad, los nuevos medios de comunicación digitales y las industrias creativas han abierto nuevas posibilidades para el desarrollo de fórmulas de atracción de turistas (Fuentes, 2005; Mehmood, 2018; Batista et al., 2020), y el poder del cine y la publicidad ha dado lugar a nuevos mecanismos basados en la creación de lazos emocionales entre cliente y destino. En una sociedad postmoderna controlada por la publicidad y los medios 
de masas (Alvarado-Sizzo et al., 2018), estos hechos contribuyen a generar un mensaje que el público interioriza, estimulando su placer visual y haciendo que adquiera la necesidad de viajar (Novo et al., 2013). Sin embargo, en palabras de Alvarado-Sizzo, Mínguez y López (2018), estas imágenes no son más que una suma de símbolos que colocan al consumidor en su propio imaginario del lugar, pues para incrementar la emoción se recurre de manera constante a desencuentros culturales y reinterpretaciones artísticas, cuya proyección no hace más que incentivar el interés por visitar lugares idealizados y mitificados que responden a representaciones reduccionistas, banalizadas y alejadas de la realidad (Puche, 2014, 2019).

En este sentido, se hace fundamental la articulación de un análisis que determine la medida en que la imagen proyectada por los poderes públicos representa la oferta real de un destino. Esto es, un análisis que permita comprobar si dicha imagen se ajusta a la realidad integral del lugar, o si, por otro lado, ha sido diseñada y alterada conscientemente para atraer turistas, anteponiendo la presentación de bienes aislados a la visión patrimonial territorial.

\section{OBJETIVOS Y METODOLOGÍA}

El presente trabajo analiza el modo en que el patrimonio ha sido asimilado por las políticas públicas de promoción a escala regional, tomando como referencia el marco institucional que representa la Junta de Andalucía y el marco temporal de los últimos cuarenta años, periodo en que las competencias en promoción turística han recaído exclusivamente en el gobierno autonómico ${ }^{2}$. En una región en la que, como se ha visto, el patrimonio representa el elemento central de la configuración de su imagen universal, en esta investigación examinamos cómo ha sido integrado éste en la creación de la que, de acuerdo con Gunn (1988), es la imagen inducida de la región, aquella creada por las organizaciones públicas del destino con objeto de influir en los individuos. Para ello se establecen los siguientes objetivos: 1 . Establecer el peso que tiene el patrimonio en la configuración de la imagen de promoción turística andaluza; 2. Determinar cómo se presenta dicho patrimonio en función del tipo de recursos utilizados y; 3. Constatar si ha existido evolución en el modo de proyección de este patrimonio, es decir, si se ha pasado de una representación de bienes monumentalista y aislada a una en la que se asuma el patrimonio en clave más territorial.

A fin de dar cumplimiento a estos objetivos se desarrolla una metodología que se articula a partir de métodos que permiten sistematizar y analizar de un modo objetivo y en términos estadísticos la información visual incluida en soportes promocionales, entendidos

2 Tras el reparto de competencias entre Gobierno Central y Comunidades Autónomas durante la transición, en su artículo 71, el Estatuto de Autonomía de Andalucía de 1981 ya atribuiría a la Comunidad la competencia exclusiva en materia de ordenación y promoción del turismo: "Corresponde a la Comunidad Autónoma la competencia exclusiva en materia de turismo, que incluye, en todo caso: la ordenación y la planificación del sector turístico; la regulación y la clasificación de las empresas y establecimientos turísticos y la gestión de la red de establecimientos turísticos de titularidad de la Junta, así como la coordinación con los órganos de administración de Paradores de Turismo de España en los términos que establezca la legislación estatal; la promoción interna y externa que incluye la suscripción de acuerdos con entes extranjeros y la creación de oficinas en el extranjero; la regulación de los derechos y deberes específicos de los usuarios y prestadores de servicios turísticos; la formación sobre turismo y la fijación de los criterios, la regulación de las condiciones y la ejecución y el control de las líneas públicas de ayuda y promoción del turismo". 
éstos como fuentes primarias. Así, es estudiado el material editado por las administraciones responsables del turismo a nivel regional desde sus inicios hasta la actualidad, en un análisis que se centra en campañas de marketing y promoción genéricas y no en material o publicaciones sobre segmentos o destinos específicos. De este modo, han sido analizadas un total de 154 imágenes promocionales publicadas por la Junta de Andalucía entre 1993 y 2017, primero a través de carteles, y después por medio del estudio de un material que se vincula mayoritariamente con internet, imágenes publicitarias estáticas destinadas a ser visualizadas en pantalla.

En este sentido, con objeto de evaluar la presencia del patrimonio en estos recursos se establece un método de análisis de los contenidos de la imagen a través del que son codificados los bienes y espacios patrimoniales según categorizaciones previamente definidas. Éste es un proceso que, de acuerdo a lo expuesto por Picazo y Moreno-Gil (2017), resulta esencial en la evaluación de la imagen proyectada por los destinos turísticos, y que ha sido usado a nivel académico de manera reiterada (Buck, 1977; Thurot y Thurot, 1983; Albers y James, 1988; Dann, 1996; Dilley, 1986; Pritchard y Morgan, 2001; Urry, 2002; Edelheim, 2007; Singh y Lee, 2009; Milman, 2011; Donaire y Galí, 2011; Matteucci y Önder, 2018). Asimismo, un posterior estudio semiológico permite analizar el significado que subyace en los anuncios turísticos oficiales (Hernández, 2008), determinando el grado y forma en que el patrimonio es incorporado a la promoción en este sector (Galí y Donaire, 2005; Nelson, 2005) a través de su contenido y composición, así como la combinación de ambos para comunicar mensajes sobre los lugares que describen (Jenkins citado por Edelheim, 2007).

Las categorizaciones propuestas para este análisis, a su vez cualitativo y cuantitativo, se adaptan a la naturaleza y características tanto del territorio objeto de estudio como del contenido visual de las propias imágenes analizadas, y en términos generales abarcan: patrimonio cultural inmueble, patrimonio cultural mueble, patrimonio cultural inmaterial, patrimonio natural, patrimonio paisajístico y otros. Posteriormente, los resultados han sido analizados siguiendo sistemas estadísticos, y contrastados con los estudios efectuados por otros investigadores con objeto de evitar la subjetividad en la organización de los materiales y lograr un enfoque consensuado (Hunter citado por Hernández, 2008).

\section{Tabla 1 \\ CATEGORÍAS PARA EL ANÁLISIS SEMIÓTICO DE LA IMAGEN INDUCIDA DE ANDALUCÍA}

\begin{tabular}{|c|c|c|}
\hline \multirow{6}{*}{$\begin{array}{l}\text { Patrimonio cultural } \\
\text { inmueble }\end{array}$} & Edificios históricos de procedencia islámica & \\
\hline & \multirow{5}{*}{$\begin{array}{l}\text { Edificios históricos de procedencia no } \\
\text { islámica }\end{array}$} & Plazas de toros \\
\hline & & Arquitectura vernácula \\
\hline & & $\begin{array}{l}\text { Otros inmuebles } \\
\text { monumentales }\end{array}$ \\
\hline & & $\begin{array}{l}\text { Yacimientos } \\
\text { arqueológicos }\end{array}$ \\
\hline & & $\begin{array}{l}\text { Arquitectura } \\
\text { contemporánea }\end{array}$ \\
\hline
\end{tabular}




\begin{tabular}{|c|c|c|}
\hline \multirow{2}{*}{$\begin{array}{l}\text { Patrimonio cultural } \\
\text { mueble }\end{array}$} & Escultura & \\
\hline & Pintura & \\
\hline \multirow{5}{*}{$\begin{array}{l}\text { Patrimonio cultural } \\
\text { inmaterial }\end{array}$} & Flamenco & \\
\hline & Gastronomía & \\
\hline & Fiestas populares & \\
\hline & Cultura de los Patios & \\
\hline & Artesanía popular & \\
\hline \multirow{8}{*}{ Patrimonio natural } & Desiertos & \\
\hline & Playas & \\
\hline & Cuevas & \\
\hline & \begin{tabular}{|l|} 
Dehesas \\
\end{tabular} & \\
\hline & Marismas & \\
\hline & Cursos de agua interior & \\
\hline & Montañas & \\
\hline & Aves & \\
\hline \multirow{3}{*}{ Patrimonio paisajístico } & Vistas urbanas & \\
\hline & Paisajes rurales de interior & \\
\hline & Paseos marítimos & \\
\hline \multirow{11}{*}{ Otros } & \multirow{5}{*}{ Deportes } & Deportes de motor \\
\hline & & Deportes acuáticos \\
\hline & & Golf \\
\hline & & Deportes de nieve \\
\hline & & Otros deportes \\
\hline & Caballos & \\
\hline & Infraestructuras de movilidad & \\
\hline & \begin{tabular}{|l|} 
Cine Western \\
\end{tabular} & \\
\hline & Spa & \\
\hline & Parques temáticos & \\
\hline & Compras y congresos & \\
\hline
\end{tabular}

\section{RESULTADOS}

Las acciones de promoción turística promovidas de manera oficial por los poderes públicos en Andalucía han recaído desde los años ochenta en la Consejería competente en materia de turismo de la Junta de Andalucía. Durante los años siguientes a la distribución de competencias entre Gobierno Central y Comunidades Autónomas fue creada la Dirección General de Turismo en la región, una entidad vinculada de manera orgánica a esta Consejería para el desarrollo de la política promocional. En su primera década de gestión, la labor desarrollada por ésta respondió a una política continuista con la promoción precedente llevada a cabo por la Administración General del Estado (Hernández, 2007, 2008), con la misma retórica, el uso de un lenguaje simbólico y planos que trataban de situar fuera del tiempo histórico los elementos patrimoniales (Puche, 2019). Para Hernán- 
dez (2007:11), la política turística desarrollada por la Junta de Andalucía entonces estaba orientada al fomento, ordenación y planificación de esta actividad en los ámbitos rural y litoral, "dejando en un segundo plano la promoción de Andalucía como unidad".

En diciembre de 1992, mismo año en que era aprobado el Plan de Desarrollo Integral del Turismo de Andalucía o Plan DIA, se constituía la empresa pública Turismo Andaluz S.A., lo que conllevaría un cambio en la política de promoción turística de la región. De esta forma, en una época en la que los esfuerzos se afanaban por frenar la tendencia al estancamiento y diversificar la oferta regional, comenzó a confeccionarse un tipo de publicidad que pretendía ofertar un producto y un servicio específico a través del eslogan Vacaciones en Hotel en Andalucía. Éste fue difundido a partir de 1993 en medios españoles con objeto de resaltar la comodidad y el bajo precio como alternativas al turismo de segunda residencia que estaba monopolizando el litoral andaluz. Además, bajo el paraguas estratégico del Plan de Promoción contenido en el Plan DIA, fueron editadas numerosas guías especializadas, guías prácticas, provinciales, de ciudades, de costa y de naturaleza, comercializándose una imagen de Andalucía dividida en seis segmentos de mercado: sol y playa; cultural; interior y naturaleza; reuniones; idiomático; y deportivo (Hernández, 2007, 2008).

Cuatro años más tarde fue creada la primera identidad corporativa para Turismo Andaluz como imagen de marca que, a través de un diseño con reminiscencias mozárabes (Cobos, 2015), partía de un concepto que ya no se fundamentaba en la comercialización de productos específicos, sino que trataba proyectar los valores de un territorio complejo, atendiendo a los deseos de los turistas a través de la evocación de sensaciones y emociones (Verdú, 2005). Se otorgaba así un significado común a los productos que se agrupaban bajo la denominación de esta marca como un destino único y amplio (Hernández, 2008), para lo que además fue concebido el nuevo eslogan Andalucía sólo hay una. Entre los objetivos de esta campaña se encontraba el de reflejar una Andalucía moderna al tiempo que fiel a sus tradiciones, valiéndose para ello de imágenes propias del patrimonio natural y cultural de la región entre las que continuaban destacando sus playas, la cultura del flamenco, pueblos blancos y monumentos icónicos como la Alhambra. Estas cuestiones se reflejan en los resultados de nuestro análisis, ya que ésta representa una de las campañas más complejas en términos estadísticos de las desarrolladas durante la etapa de gestión autonómica, con un 16,67\% de carteles en los que el protagonista era el patrimonio inmueble de Andalucía; un $22,22 \%$ de imágenes alusivas al patrimonio natural; o un $27,78 \%$ calificadas como otras, entre las que destacaban las referencias a prácticas deportivas. Sin embargo, uno de los hitos más destacados de esta campaña es que, pese a que no fue hasta el año 2003 cuando UNESCO reconocía la necesidad de protección del patrimonio cultural inmaterial $^{3}$, y que habría que esperar hasta 2015 para que entrara en vigor una ley estatal para su protección ${ }^{4}$, casi una quita parte de los carteles editados en 1997, el 19,44\% de éstos, tenía como protagonista manifestaciones etnológicas de Andalucía.

3 Convención para la Salvaguarda del Patrimonio Cultural Inmaterial.

4 Ley estatal 10/2015 para la salvaguarda del Patrimonio Cultural Inmaterial. 


\section{Imagen 2}

\section{CARTELES DE LA CAMPAÑA ANDALUCÍA SÓLO HAY UNA DE 1997}

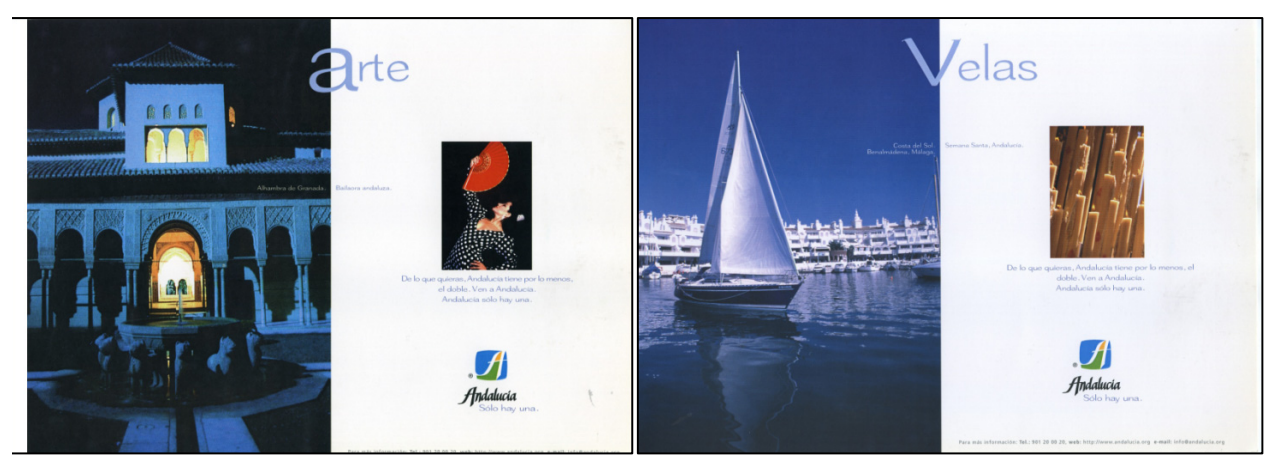

En el año 2001 se presentaba una nueva campaña que, manteniendo el lema Andalucía solo hay una, proponía un diseño nuevo, en palabras del propio Centro de Documentación de la Consejería de Turismo, Comercio y Deporte (2007:97), “diferente, atrevido y rompedor". El objetivo de la misma era el de proyectar la región como una tierra de fuertes contrastes, un destino ideal para escapar de la rutina. Entre las imágenes de la campaña genérica, el patrimonio inmaterial llegaba a protagonizar un tercio del total de los carteles editados, existiendo escasas reminiscencias al patrimonio inmueble o natural: apenas 2 representaciones del primero -una de ellas con la Alhambra como protagonista; y 3 sobre el segundo. Sin embargo, destaca una imagen que por primera vez presentaba a Andalucía a través de una vista urbana en la promoción oficial, pues, para aludir a las compras, ésta se valía de una representación de las calles de la Alcaicería granadina, un barrio fundado en el siglo XIV y reconstruido en 1843 siguiendo un estilo romántico y neomudéjar. Al mismo tiempo, otra imagen en la que la gastronomía era la protagonista del encuadre, con un bodegón tradicional en primer plano, usaba un escenario en el que predominaba una arquitectura de estilo orientalista (imagen 3).

Un año más tarde, el eslogan de las campañas andaluzas pasó a ser Andalucía sólo hay una, la tuya. Pese a que bajo el mismo se pretendía continuar resaltando la diversidad del destino, cerca de una quinta parte de las imágenes de la campaña eran protagonizadas por la Alhambra o la Mezquita de Córdoba, mismo volumen que representaban las playas, en detrimento del patrimonio inmaterial o las alusiones a la práctica deportiva. Además de este reduccionismo en términos patrimoniales, el uso de un lenguaje que empleaba la palabra Culto, la aplicación de tonalidades cálidas, la desaparición de personas de los encuadres, o la proyección de imágenes que mostraban una naturaleza frágil supondrían elementos que potenciarían el tono nostálgico de la campaña (Hernández, 2007), favoreciendo una presentación atemporal de la región (imagen 4). 


\section{Imagen 3}

\section{CARTELES DE LA CAMPAÑA ANDALUCÍA SÓLO HAY UNA DE 2001}
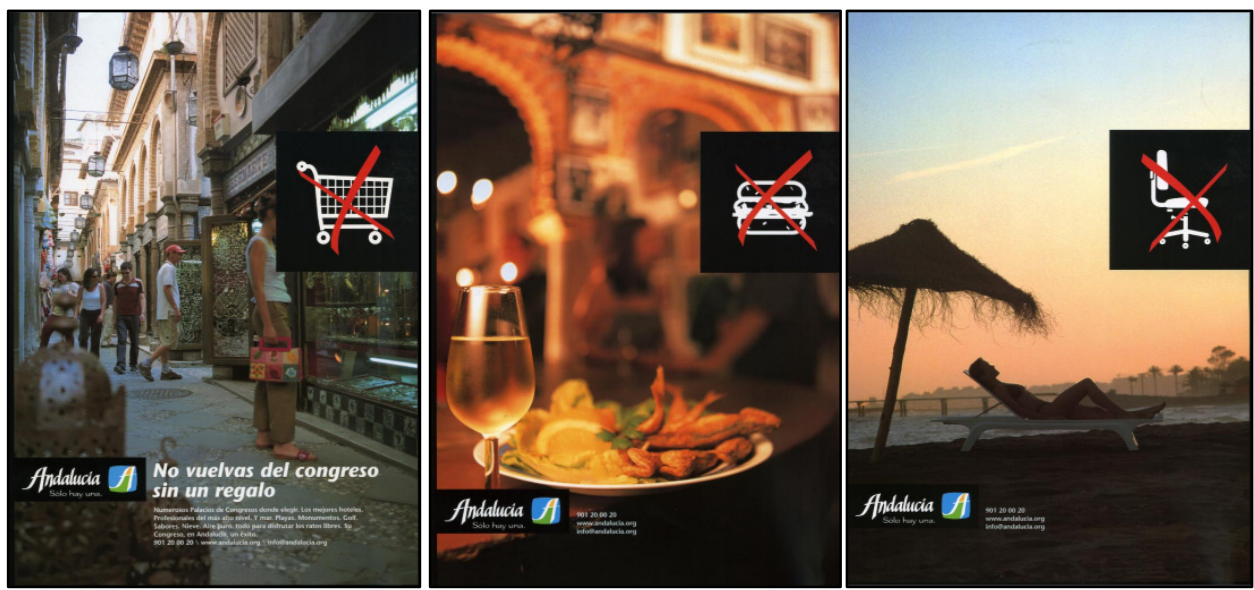

\section{Imagen 4}

CARTELES DE LA CAMPAÑA ANDALUCÍA SÓLO HAY UNA, LA TUYA DE 2002

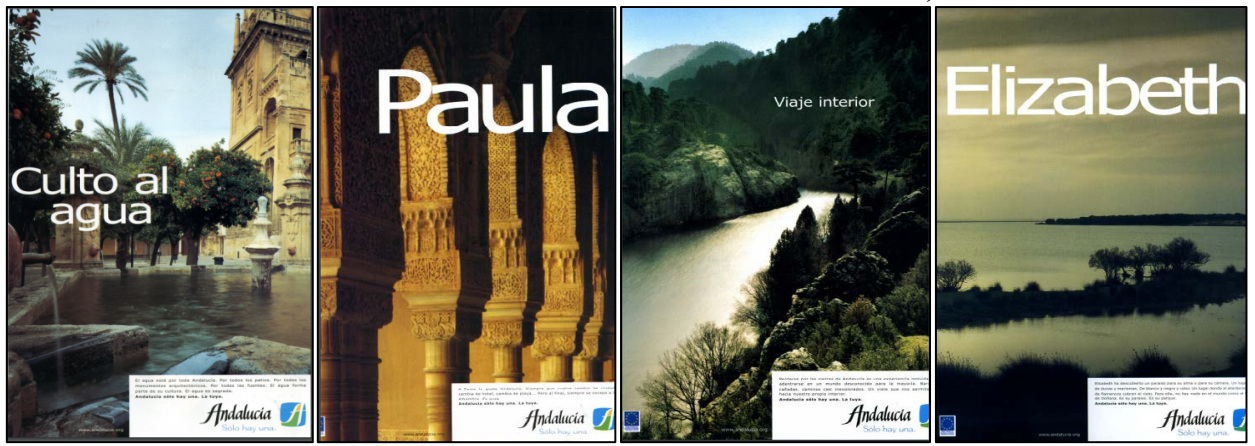

En 2004, la aprobación del Plan General de Turismo y el Plan Director de Marketing Turístico de Andalucía, así como del Decreto 461/2004 sobre coordinación de la Comunicación Corporativa de la Administración de la Junta de Andalucía favoreció que se produjera una reordenación estratégica de la promoción regional. Este ejercicio trataba de compatibilizar el desarrollo con la recuperación del patrimonio y la calidad medioambiental, ampliando la imagen de Andalucía a múltiples sectores de una manera unificada. Ese mismo año fue diseñado el eslogan Andalucía te quiere, con el que se pretendía posicionar al territorio como un destino turístico de calidad, con buenas infraestructuras y preocupado por el medioambiente (Cobos, 2015), al tiempo que amable y hospitalario con el visitante (Centro de Documentación de la Consejería de Turismo, Comercio y Deporte, 2007). Frente a la 
anterior, esta campaña fue la primera en la que aparecían personas en la totalidad de las imágenes emitidas, lo que según Garrido (2005) antropomorfizaba el territorio, mostrando una relación amorosa entre el visitante y el espacio. Sin embargo, y pese a que se trataba de una campaña en la que la visión decimonónica era menos explícita, las tonalidades y escenarios elegidos siguieron siendo propios del gusto romántico, con paisajes prístinos y atemporales.

\section{Imagen 5}

CARTELES DE LA CAMPAÑA ANDALUCÍA TE QUIERE DE 2004

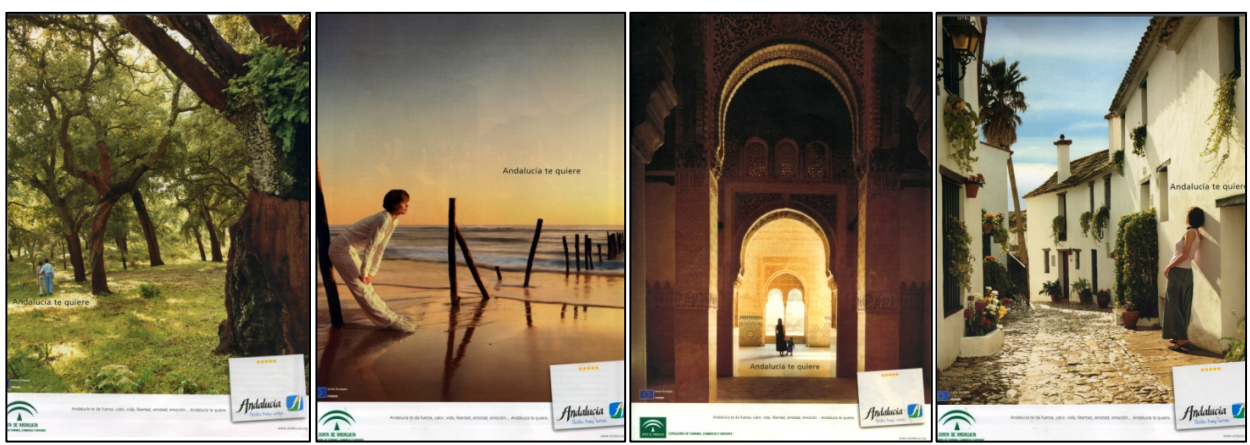

Un año después, la Junta llevaba a cabo, junto a Turespaña, la campaña Smile! You are in Andalucía. Para Fuentes (2005) ésta representaba la misma idea del Spainis Different, suponiendo una reiteración de elementos propios de la imagen más tópica de la región. Así, el material editado insistía en recursos como el flamenco, la arquitectura musulmana, la gastronomía o el buen clima para disfrutar del golf y la playa. Y es que el objetivo de ésta era reforzar la marca España en los mercados internacionales (Martínez y Nicolás, 2014), valiéndose para ello de representaciones ya consolidadas en el imaginario general junto a la presentación del propio público objetivo.

\section{Imagen 6 \\ CARTELES DE LA CAMPAÑA SMILE! YOU ARE IN ANDALUCIA DE 2005}

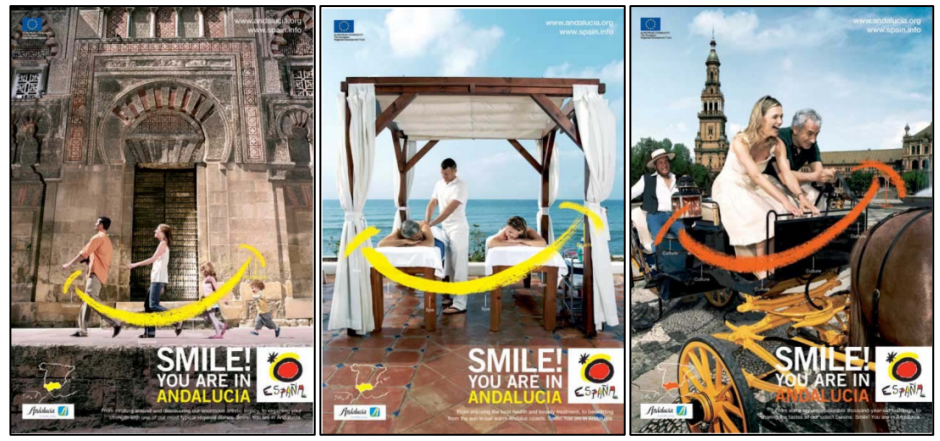


En los años siguientes la campaña Andalucía te quiere prosiguió estrenando carteles en los que el patrimonio inmueble de reminiscencias islámicas continuaba gozando de gran protagonismo. De manera principal éste estaba presente en el 30\% del total de la promoción. Además se aludía al mismo en otros materiales como en un cartel que por primera vez era protagonizado por un balneario, con el uso de un espacio arquitectónico enmarcado por columnas con arcos de herradura y tragaluces estrellados. Los cursos de agua interiores ocupaban el mismo porcentaje que las playas $-16,67 \%-$, y el paisaje rural de interior, al igual que en las campañas anteriores, era representado por medio de una panorámica de casas blancas en medio de un singular entorno natural. La campaña no transmitía la imagen íntima y personalizada anterior, proyectando lugares espectaculares que esperaban a ser explorados (Martínez y Nicolás, 2014).

\section{Imagen 7 \\ CARTELES DE LA CAMPAÑA ANDALUCÍA TE QUIERE DE 2006}

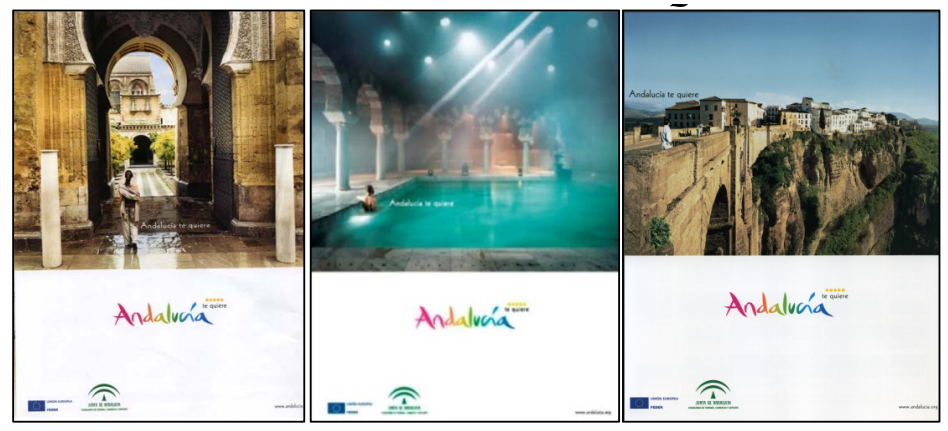

En 2014 se puso en marcha la campaña Tu mejor tú, donde los protagonistas eran visitantes que llevaban a cabo actividades relacionadas con diferentes segmentos turísticos, en lo que se ha considerado un intento por mostrar la infinidad de la oferta andaluza, pero que volvía a recurrir de manera reiterada a imágenes del folclore regional (Cobos, 2015). Recursos como el sol y playa, el paisaje rural de interior a través panorámicas prototípicas, o la arquitectura de rasgos nazaríes volvían a ser protagonistas de una quinta parte de la promoción en el caso de los dos primeros, y un $30 \%$ en lo relativo al patrimonio musulmán. Estos carteles presentaban una serie de connotaciones preestablecidas de la región como lugar en el que encontrar entornos idílicos donde vivir sensaciones que hacen aflorar lo mejor de cada persona (Zapata, 2018), mostrando un Sur definido por su oposición al Norte, donde el clima es cálido, y se dan cabida la diversión, la quietud y la vida al aire libre (Francescutti, 2016). 


\section{Imagen 8}

CARTELES DE LA CAMPAÑA TU MEJOR TÚ DE 2014
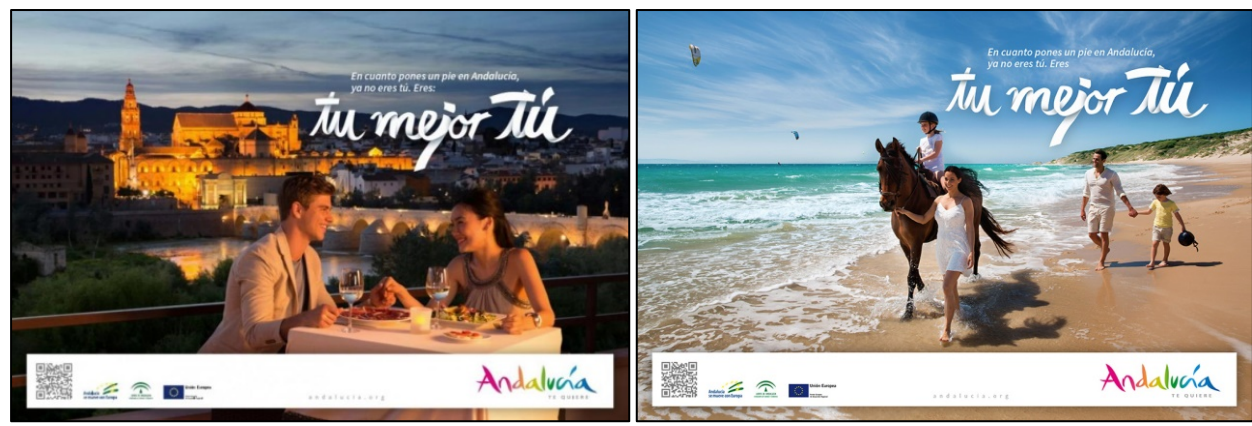

\section{Imagen 9}

IMÁGENES DE LA CAMPAÑA INTENSAMENTE EN LA WEB OFICIAL DE LA EMPRESA PÚBLICA PARA LA GESTIÓN DEL TURISMO Y DEL DEPORTE

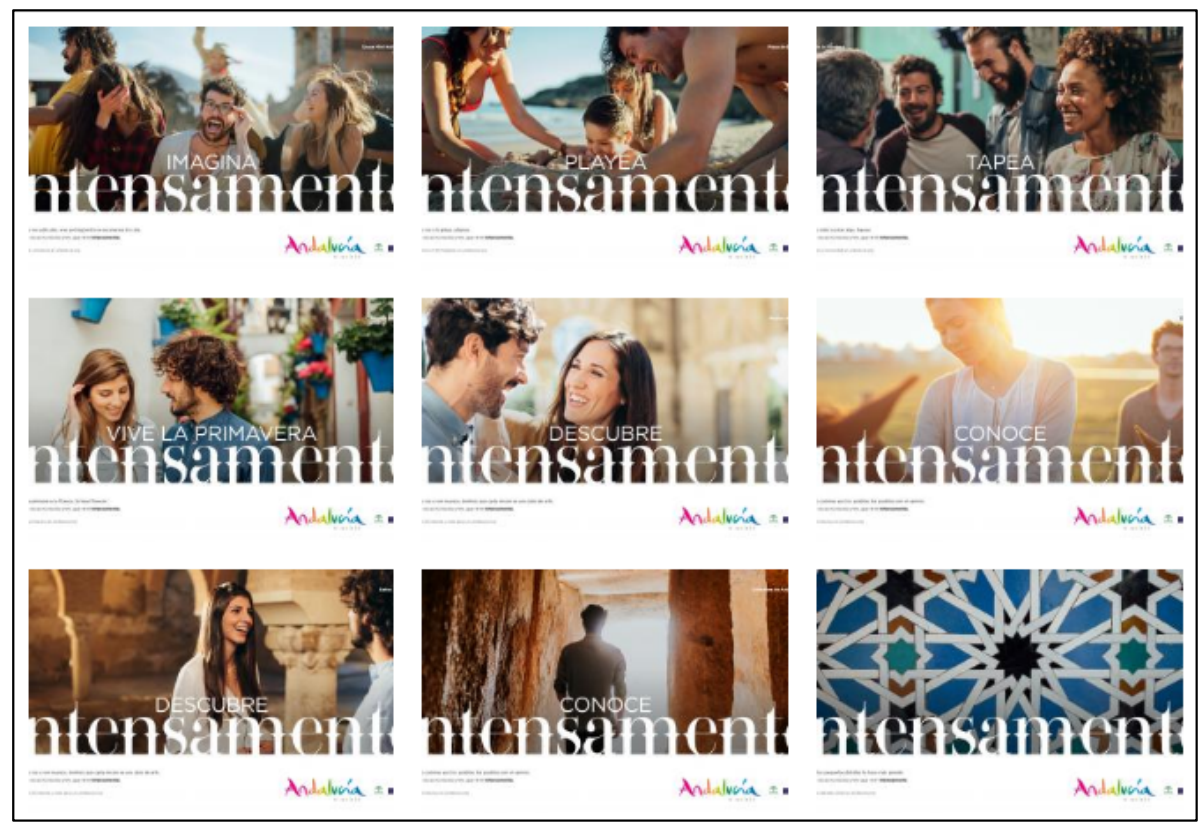

Del mismo modo, en 2017 era presentada la campaña Intensamente, que, al tiempo que pretendía destacar la conexión sensorial y emocional que sentirían los visitantes en el destino, hacía uso de los mismos elementos que protagonizaban las campañas ante- 
riores, con el patrimonio andaluz como escenario de vivencias y planos detalle a partir de recursos que habían sido habituales ya en textos decimonónicos (imagen 9). Así, el análisis del material de esta campaña desvela que de las 40 fotografías que componen el conjunto promocional, 17 tienen como fondo elementos propios del patrimonio cultural de Andalucía, 11 de ellas bienes inmuebles de corte monumental de los que 8 son de origen musulmán, cifra que supone una quinta parte del total. Muchas de estas fotografías están vinculadas a bienes como la Alhambra o Medina Azahara, incluida en la Lista del Patrimonio Mundial en 2018, representando el mismo porcentaje que las playas. También los entornos paisajísticos cuentan con buena presencia, destacando fotografías de entornos históricos o pueblos blancos entre paisajes montañosos o de marismas.

\section{DISCUSIÓN}

La promoción turística llevada a cabo por las instituciones autonómicas durante las últimas décadas muestra una notable evolución hacia planteamientos cada vez más holísticos de la oferta andaluza, pues las representaciones de la región que han venido siendo proyectadas durante los últimos años incorporan segmentos y recursos antes ausentes en las acciones promocionales. En este sentido, segmentos turísticos en auge como el de compras y congresos, el relacionado con el wellness o el vinculado a los parques temáticos han sido incorporados a la promoción turística regional más reciente, reduciendo la proporción de bienes y espacios patrimoniales en las imágenes emitidas por las instituciones. Además, existen otros segmentos como el ligado al golf que han sido frecuentemente utilizados en estas campañas durante el periodo temporal analizado. Pese a ello, un importante porcentaje de imágenes continúa aludiendo a bienes y recursos patrimoniales que ya fueran exaltados durante el Romanticismo y que se han consagrado como parte fundamental de la imagen universal de la región, lo que nos permite dar respuesta al objetivo número uno de nuestra investigación afirmando que el patrimonio continúa teniendo un peso muy significativo en la configuración de la imagen turística promocional andaluza.

Este es el caso del patrimonio cultural inmueble del periodo de Al-Ándalus, que acapara el $15,58 \%$ del total de las representaciones exhibidas en las campañas analizadas y se sitúa como la categoría más reproducida en la promoción autonómica oficial durante las últimas décadas. Lo mismo ocurre con la representación de la naturaleza en su versión más prístina y solitaria, que es proyectada por las autoridades autonómicas por medio de imágenes donde no hay transformaciones antrópicas, y donde habitan las aves en estado salvaje -casi un $2 \%$ del total de la promoción representa especies avícolas. Estas imágenes, ligadas a espacios montañosos y boscosos, con cerros escarpados, gargantas y cañones propios del paisaje subalpino tan reclamado por el imaginario invernal occidental difundido desde el Romanticismo (Prats, 2011), suponen una cuarta parte del material editado en las campañas publicitarias analizadas. Todo ello implica la continuación de la proyección de estereotipos por parte de los agentes implicados en la promoción turística regional, con la conformación de una imagen inducida basada en un escenario aún no estropeado (Francescutti, 2016), en muchas ocasiones atemporal e incluso evocador del periodo victoriano. 
Otro de los tópicos de la imagen romántica andaluza que viene siendo continuamente reiterado en las campañas promocionales contemporáneas es el patrimonio paisajístico rural de interior, generalmente representado a través de pueblos pintorescos de fachadas blancas sobre cumbres escarpadas, y que supone el 7,14\% de estas imágenes. Asimismo, la gastronomía es otro de los elementos de difusión publicitaria más destacados, alcanzando el 6,49\% del total de las representaciones en estas campañas. En ambos casos es preciso señalar que los escenarios aparecen representados por elementos propios del pasado musulmán de la península en un destacado número de imágenes, con reminiscencias a fortalezas, a una arquitectura vernácula donde es protagonista la cal, o a elementos arquitectónicos de estilo neomudéjar.

Además, son comunes en estas campañas las referencias a localizaciones ampliamente enaltecidas por la promoción turística de la etapa fordista durante la segunda mitad del siglo XX en España, como las playas. Éstas, que representan el 13,64\% de la promoción desarrollada por la Junta de Andalucía desde 1993, aparecen en la mayor parte de ocasiones proyectadas como espacios casi vírgenes, con cielos despejados y tonalidades cálidas, pese a que el litoral andaluz ha sufrido una notable urbanización que se ha traducido en un intensivo uso del suelo para fines turísticos (Hernández, 2007). Asimismo, a lo largo de los últimos años se detecta un cambio en estas representaciones, que han tornado hacia escenarios de dinamismo donde la gente ya no solo se tumba al sol, sino que corre, juega y practica deporte.

Tabla 2

PRESENCIA DEL PATRIMONIO EN LAS CAMPAÑAS PROMOCIONALES DE ANDALUCÍA DESDE 1993 A 2017 SEGÚN PORCENTAJES

\begin{tabular}{|c|c|c|c|c|c|c|c|c|c|}
\hline Año & 1993 & 1997 & 2001 & 2002 & 2004 & 2005 & 2006 & 2014 & 2017 \\
\hline Campaña & 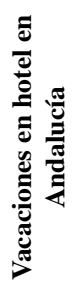 & 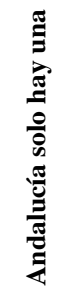 & 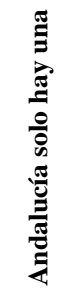 & 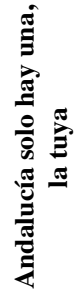 & 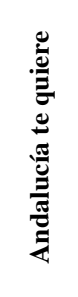 & 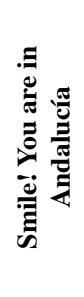 & 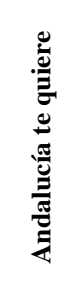 & 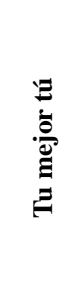 & 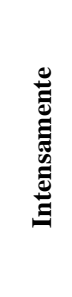 \\
\hline $\begin{array}{l}\text { Edificios históricos de } \\
\text { procedencia islámica }\end{array}$ & 20,00 & 5,56 & 6,67 & 18,75 & 12,50 & 14,29 & 25,00 & 30,00 & 20,00 \\
\hline Plazas de toros & 10,00 & 2,78 & - & - & - & - & - & - & - \\
\hline Arquitectura vernácula & - & 2,78 & 6,67 & 12,50 & 25,00 & - & 8,33 & - & 2,50 \\
\hline Otros inmuebles monumentales & 10,00 & 5,56 & - & - & 12,50 & 14,29 & 8,33 & - & - \\
\hline Yacimientos arqueológicos & - & - & - & - & - & - & - & - & 2,50 \\
\hline Arquitectura contemporánea & - & - & - & - & - & - & - & - & 2,50 \\
\hline Escultura & 30,00 & 2,78 & - & - & - & - & - & - & - \\
\hline
\end{tabular}




\begin{tabular}{|c|c|c|c|c|c|c|c|c|c|}
\hline Pintura & - & 2,78 & - & - & - & - & - & - & 2,50 \\
\hline Flamenco & 10,00 & 2,78 & - & - & - & 14,29 & - & - & 2,50 \\
\hline Gastronomía & 10,00 & 5,56 & 13,33 & - & - & 28,57 & - & - & 7,50 \\
\hline Fiestas populares & - & 5,56 & 13,33 & 6,25 & - & - & - & - & - \\
\hline Cultura de los Patios & - & 2,78 & - & - & - & - & - & - & 2,50 \\
\hline Artesanía popular & - & 2,78 & 6,67 & - & - & - & - & - & - \\
\hline Desiertos & - & 2,78 & - & - & - & - & - & - & - \\
\hline Playas & - & 5,56 & 13,33 & 18,75 & 12,50 & 14,29 & 16,67 & 20,00 & 20,00 \\
\hline Cuevas & - & 2,78 & - & - & - & - & - & - & - \\
\hline Dehesas & 10,00 & 2,78 & - & - & - & - & - & - & - \\
\hline Marismas & - & - & - & 6,25 & 12,50 & - & - & - & - \\
\hline Cursos de agua interior & - & 2,78 & - & 6,25 & - & - & 16,67 & - & 7,50 \\
\hline Montañas & - & 2,78 & - & - & - & - & - & - & 2,50 \\
\hline Aves & - & 2,78 & 6,67 & 6,25 & - & - & - & - & - \\
\hline Vistas urbanas & - & - & 6,67 & - & - & - & - & 10,00 & 5,00 \\
\hline Paisajes rurales de interior & - & 5,56 & 6,67 & 6,25 & 12,50 & - & 8,33 & 20,00 & 7,50 \\
\hline Paseos marítimos & - & 2,78 & - & - & 12,50 & - & - & 10,00 & - \\
\hline Deportes de motor & - & 5,56 & - & - & - & - & - & - & - \\
\hline Deportes acuáticos & - & 8,33 & 6,67 & 6,25 & - & - & - & - & - \\
\hline Golf & - & 2,78 & 6,67 & 6,25 & - & 14,29 & 8,33 & 10,00 & 5,00 \\
\hline Deportes de nieve & - & - & 6,67 & - & - & - & - & - & - \\
\hline Otros deportes & - & 2,78 & - & - & - & - & - & - & 2,50 \\
\hline Caballos & - & 5,56 & - & - & - & - & - & - & - \\
\hline Infraestructuras de movilidad & - & 2,78 & - & 6,25 & - & - & - & - & - \\
\hline Cine Western & - & - & - & - & - & - & - & - & 2,50 \\
\hline Spa & - & - & - & - & - & - & 8,33 & - & - \\
\hline Parques temáticos & - & - & - & - & - & - & - & - & 2,50 \\
\hline Compras y congresos & - & - & - & - & - & - & - & - & 2,50 \\
\hline
\end{tabular}

Por tanto, en las campañas llevadas a cabo desde 1993 por parte de las autoridades autonómicas en Andalucía, el patrimonio es representado de manera general a través de bienes de tipo inmueble -el 27,27\% de las ocasiones-, o por medio de representaciones de espacios naturales sin antropizar-25,32\%-, donde las playas ocupan casi la mitad de éstas, así como con imágenes de paisajes rurales de interior. Si bien, y pese a que la incorporación de nuevos sectores ha favorecido una mayor diversificación de la imagen turística proyectada, el pasado árabe de la región está presente no solo de manera protagonista en más de una sexta parte de la promoción desarrollada, sino que además aparece como escenario en las que otro tipo de bienes ocupan el rol principal. Este estudio estadístico, por tanto, constata la idea de que la imagen inducida de Andalucía es herencia de la identidad 
universal de la región construida durante el Romanticismo, dando repuesta al objetivo número dos de nuestra investigación.

En cuanto al tercero de los objetivos planteados, el análisis aquí llevado a cabo da cuenta de que la promoción turística andaluza se ha valido de una óptica integral desde hace décadas, con el uso de imágenes en las que los bienes aparecen indisociables de su entorno. Pese a ello, es posible afirmar que esta visión más integral se ha acrecentado con una menor utilización de planos cortos en la toma de las fotografías, o la incorporación de un mayor número de encuadres donde la óptica territorial del patrimonio es más evidente: inmuebles que aparecen en medio de un contexto urbano complejo, primeros planos de personas que disfrutan de un espacio diverso, productos gastronómicos que se representan a través de alegorías en el paisaje, etc.

\section{CONCLUSIONES E IMPLICACIONES}

En un mercado turístico tan diverso y competitivo como el actual a nivel global, las administraciones públicas se valen de la imagen del territorio para generar interés y seducir al turista potencial favoreciendo su preferencia por el mismo y, en última instancia, provocar su desplazamiento hasta él. Para ello, las imágenes universales de los territorios, aquellas consolidadas en el imaginario general a lo largo del tiempo, ejercen en muchas ocasiones de sustento sobre el que configurar las representaciones inducidas elaboradas por los agentes responsables de la promoción de los destinos, pues éstas se basan en conceptos icónicos y fácilmente reconocibles. Así es común la utilización de representaciones enriquecidas, imágenes que puedan ser percibidas como ideales, propias de un entorno que invita al visitante a alcanzar la plena felicidad en paisajes y entornos idílicos y atemporales.

En este sentido, la imagen universal de la Comunidad Autónoma de Andalucía se ha consolidado como una imagen prototípica fraguada durante los siglos XVII y XIX, con el redescubrimiento de esta región por parte de las clases altas europeas. En ella, esta tierra es asimilada como exótica y rica en contrastes, como un lugar donde encontrar las reminiscencias a un mundo árabe lejano y extravagante, que unido al clima y las tradiciones, ha forjado un conjunto icónico de gran recorrido en el imaginario general occidental. De este modo, el patrimonio cultural, natural y paisajístico ha tenido una importancia trascendental en la construcción de la imagen de Andalucía, en gran medida debido al interés que existiera durante la Ilustración por las sociedades del pasado y, por ende, por los testimonios dejados por las mismas. Entonces, la región más meridional del país se erguiría como la más representativa y enigmática de la península, llegando incluso a constituirse en sinónimo de todo lo español (García, 1995; Carrère-Lara, 2001; Garayo, 2001; Calatrava, 2018). Andalucía suponía la puerta de África (Galant, 2018), lo que hacía que fuera percibida como un territorio lleno de contrastes y difícil de catalogar, una región de un alto exotismo que aunaba lo más tópico de las tradiciones árabes y el mundo cristiano medieval, aspectos que consolidaban al lugar como destino ideal para unas clases altas europeas que habían redescubierto la cultura popular como objeto de interés a explorar. Así, y pese a que la imagen proyectada de Andalucía resultaba compleja y rica en matices, subyacían ciertos planteamientos en torno a los cuales se articulaban la mayor parte de los 
textos y grabados, como lo salvaje, la Edad Media o la cultura de lo Oriental, elementos que eran constantemente exaltados.

Este fenómeno ha favorecido que la estética historicista esté muy vigente incluso a día de hoy en la imagen turística oficial proyectada de la región, con la presencia de rasgos básicos que van de la africanidad, al relieve montañoso asociado al temperamento de sus pobladores, la magnificencia de los monumentos islámicos o la cultura popular, rasgos de concepción romántica que en gran medida se han convertido en la quintaesencia de la imagen universal andaluza, conformada a partir de tópicos que han perdurado hasta la actualidad.

El análisis puesto en marcha en esta investigación ha permitido determinar que, aunque la proyección que se ha llevado a cabo por parte de los organismos responsables de la promoción turística en la Comunidad de forma más reciente es diversa y heterogénea, los estereotipos no han dejado de ser una constante en las acciones de comunicación y promoción. Así, en las campañas llevadas a cabo por la Empresa Pública para la Gestión del Turismo y del Deporte de Andalucía desde 1993 la riqueza monumental ha continuado siendo la gran protagonista, pese a que la región ha sido vinculada a una oferta turística cada vez más variada. No obstante, en un número muy elevado de casos, dichas campañas han sido protagonizadas por espacios naturales apenas antropizados, así como por bienes inmuebles, especialmente de origen medieval vinculados al periodo de Al-Ándalus que, del mismo modo que ya hicieran siglos atrás los viajeros foráneos, han sido proyectados como escenarios donde vivir experiencias únicas (Rodríguez, 2000). Y es que la mayor parte de los bienes y espacios representados en estas campañas suponen los mismos elementos que ya fueran exaltados por los viajeros británicos, franceses o alemanes durante sus viajes por tierras andaluzas siglos atrás.

Por tanto, existe una inercia romántica en las representaciones proyectadas de Andalucía. Esto es, que las imágenes turísticas inducidas están muy condicionadas por las imágenes universales de la región. Dicha continuidad de rasgos del pasado estaría fundamentada en que éstos suponen atractivos de fácil apropiación fotográfica, percepciones bien asentadas en el imaginario colectivo, con lo que se facilita su reconocimiento en un mercado complejo y variado como el actual. Sin embargo, sus componentes han sido, en palabras de Hernández (2007:20), “dulcificados en sus aspectos más controvertidos porque podrían frenar la llegada de turistas", como en el caso de las corridas de toros, cuya desaparición en la promoción oficial se justifica en la controversia que el toreo genera en la actualidad y su cada vez mayor denostación social.

A este uso continuado de bienes y espacios ya valorados durante el Romanticismo se suma la utilización de encuadres que llegan a reproducir perspectivas y momentos reiterados por autores decimonónicos, en una clara intención por generar una idea de Andalucía como un territorio atemporal y enigmático. 


\section{Imagen 10 \\ RELACIONES VISUALES ENTRE GRABADOS DECIMONÓNICOS 5 E IMÁGENES PROMOCIONALES EDITADAS POR LA JUNTA DE ANDALUCÍA}

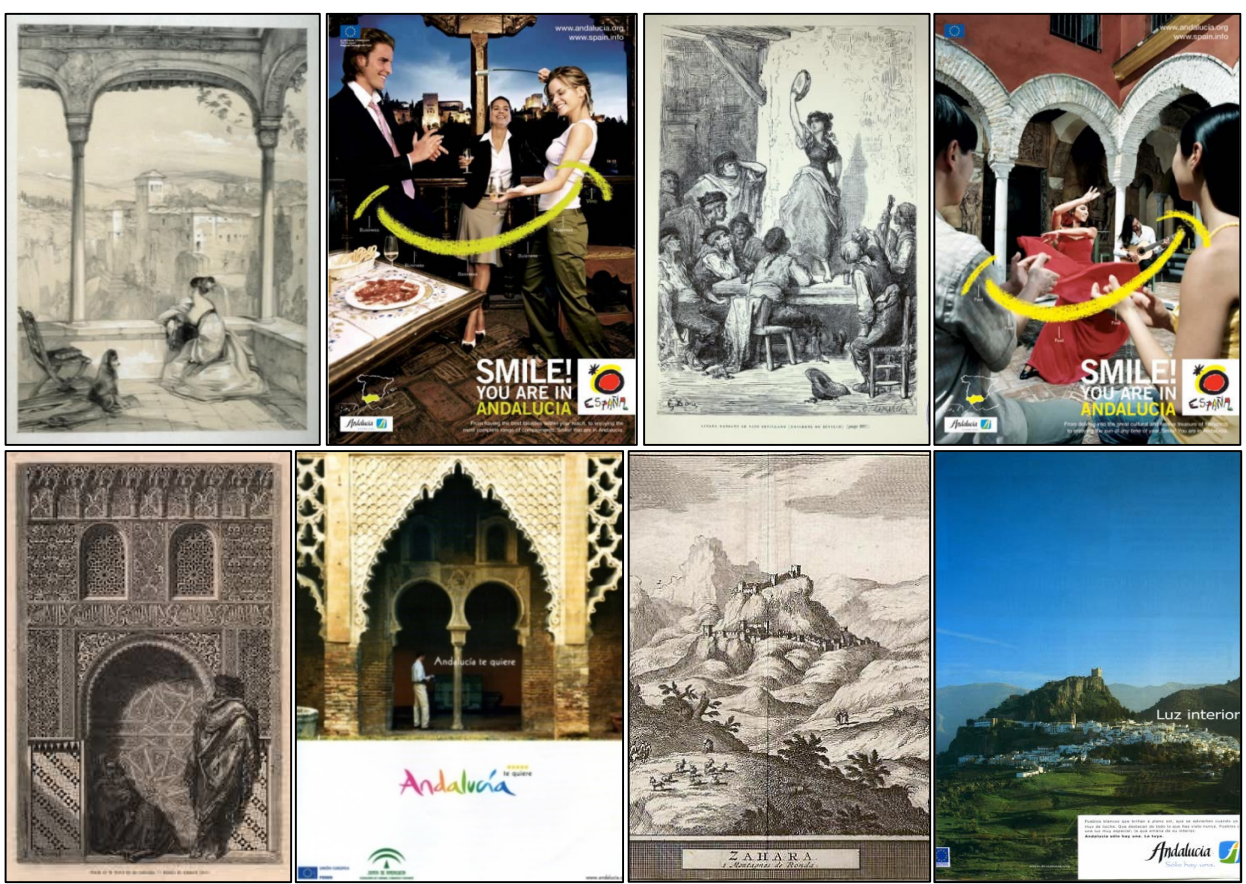

Asimismo, se percibe un cambio en la presencia de los sujetos, pasándose de representaciones de lugares vacíos en 1993 a una residual aparición de actores cuatro años más tarde, hasta llegar a ser éstos una constante en las campañas más recientes. Adicionalmente, se ha producido una variación en la forma en que estos sujetos han sido incorporados, ya que mientras que a finales de la década de los noventa éstos eran personajes nativos representados como parte del escenario, de rasgos físicos de influencia árabe y raza gitana, en las campañas posteriores se produce la aparición del propio turista potencial disfrutando del destino. Este turista es representado en numerosas ocasiones como un sujeto neorromántico que, según Hernández (2007), admira el espacio mientras lleva a cabo un viaje en el tiempo.

La voluntad institucional por diferenciar el destino turístico andaluz a partir de unos patrones en línea con el imaginario colectivo global implica el desarrollo de dinámicas de resignificación de ciertos bienes y espacios. Y es que, pese a que el turismo juega un rol esencial en la estimulación de la conservación, valorización y recuperación del patri-

5 Distant View of the Sierra Nevada, John F. Lewis, litografía, 1836; Gitana dansant le Vito Sevillano, Gustave Doré, xilografía, 1874; Puerta de la torre de las Infantas, Gustave Doré, xilografía, 1864; Zahara, Álvarez de Colmenar, grabado en plancha de cobre, 1707. 
monio, el papel de éste como pieza clave en el desarrollo turístico de la región andaluza ha acabado por imponerse a su lectura según valores culturales o naturales, y las lógicas del mercado, medidas en términos cuantitativos -número de visitas o rentabilidad económica-, han acabado por superar a las vinculadas con la conservación y difusión de dichos valores. Durante su visita, los turistas quieren conocer los bienes que se proyectan desde el destino como emblemas del mismo, lo que puede dar lugar a un incremento en el flujo de visitas y, en última instancia, una superación de la capacidad de carga de estos bienes y conjuntos patrimoniales, afectado a su conservación o a la propia calidad de la visita. Las representaciones de Andalucía continúan mostrando en gran medida espacios idealizados y auténticos, anclados en un pasado de reminiscencias exóticas, lo que conlleva que gran parte del patrimonio cultural y natural de la región que no cumple con los cánones dieciochescos sea excluido de dicha promoción, provocando una segregación y un reforzamiento de los estereotipos visuales por parte de las propias instituciones.

La continua profusión de imágenes proyectadas con el fin de captar clientes puede contribuir a un cambio en la forma en que la propia población local percibe su entorno, más cercano cada vez a la noción de escenario, con la incorporación de lecturas del territorio más estéticas. Este hecho contribuye a afianzar los procesos de museificación, transformando el espacio patrimonial en turístico. El destino es construido de acuerdo con los deseos y expectativas de los potenciales visitantes, lo que puede conllevar importantes consecuencias de carácter socio-territorial.

Declaración responsable: Los autores declaran que no existe ningún conflicto de interés en relación a la publicación de este artículo. Las tareas se han distribuido del modo siguiente. El diseño general del artículo ha correspondido a J. David Albarrán, que también ha elaborado el marco teórico, ha recopilado la información de base del trabajo y ha procedido al análisis de los materiales. Manuel de la Calle ha acotado el objeto de investigación, redefinido los objetivos y guiado los apartados de discusión y conclusiones. El diseño metodológico, la revisión bibliográfica y la extracción de las conclusiones han sido responsabilidad de ambos autores.

\section{BIBLIOGRAFÍA}

ALBARRÁN PERIÁÑEZ, J.D. (2021): “Territorial image construction: an original perspective from the outsider", en UNA Europa PHD Workshop. Heritage Hybridisations concepts, scales and spaces. París, UNA Europa, Universidad Paris 1 PanthéonSorbonne.

ALBERS, P. y JAMES, W.R. (1988): “Travel photography. A methodological approach", Annals of Tourism Research, vol. 15 (1), pp. 134-158.

ALVARADO-SIZZO, I., MÍNGUEZ GARCÍA, M.C. y LÓPEZ LÓPEZ, Á. (2018): "Representaciones visuales de los destinos turísticos a través de Internet: el caso de Valladolid (México)", PASOS. Revista de Turismo y Patrimonio Cultural, vol.16 (2), pp. 335-351. ÁLVAREZ-SOUSA, A. (2015): "Imagen, lealtad y promoción turística. Análisis con ecuaciones estructurales", PASOS. Revista de Turismo y Patrimonio Cultural, vol.13 (3), pp. 629-648. 
ANDRADE SUÁREZ, M.J. (2011): “La formación de la imagen turística desde la perspectiva de la distancia cultural del viajero. Marco teórico y estudio de caso", Estudios y Perspectivas en Turismo, vol. 20 (6), pp. 1.237-1.257.

ANDREU, L., BIGNÉ, J.E. y COOPER, C. (2000): "Projected and Perceived Image of Spain as a Tourist Destination for British Travellers", Journal of Travel y Tourism Marketing, vol. 9 (4), pp. 47-67.

ASHWORTH, G. (1990): "Products, Places and Promotion: Destination Images in the Analysis of the Tourism Industry", en Marketing Tourism Places. Londres, Routledge, pp. 121-142.

BALOGLU, S. y MCCLEARY, K.W. (1999): “A model of destination image formation”, Annals of Tourism Research, vol. 26 (4), pp. 868-897.

BANCO MUNDIAL (2019): Turismo internacional, recibos (\% del total de exportaciones) - Spain. Organización Mundial del Turismo, Anuario de estadísticas de turismo, Compendio de estadísticas de turismo y archivos de datos, y estimaciones de exportaciones del FMI y el Banco Mundial.

BARKE, M. y TOWNER, J. (1996): "Exploring the History of Leisure and Tourism in Spain”, en Tourism in Spain: Critical Issues. Wallingford, CAB International, pp. 3-34.

BARRIO GARCÍA, S., LUQUE MARTÍNEZ, T. y RODRÍGUEZ MOLINA, M.A. (2009): "La modernización de la imagen de la ciudad desde la perspectiva de los líderes de opinión externos", EURE, vol. 35 (106), pp. 9-28.

BARTHES, R. (1957): Mitologías. Ciudad de México. Siglo XXI ediciones.

BATISTA SÁNCHEZ, E., SERRANO LEYVA, B. y PÉREZ RICARDO, E.C. (2020): "Bibliometric study of tourism destination image in Science Direct", Revista Interamericana de Ambiente y Turismo, vol .16 (1), pp. 97-105.

BERGER P. y T. LUCKMANN (1986): La construcción social de la realidad (Cap. III). Buenos Aires, Amorrortu.

BERNAL RODRÍGUEZ, M. (1985): La Andalucía de los libros de viajes del siglo XIX (Antología). Sevilla, Editoriales Andaluzas Unidas.

BERNO, T. y WARD, C. (2005): "Innocence Abroad: A Pocket Guide to Psychological Research on Tourism", American Psychologist, vol. 60 (6), pp. 593-600.

BIGNÉ ALCAÑIZ, E., SÁNCHEZ GARCÍA, I. y SÁNCHEZ GARCÍA, J. (2001): "Tourism Image, Evaluation Variables and After Purchase Behaviour: InterRelationship", Tourism Management, vol. 22 (6), pp. 607-616.

BOURGOING, J.F. (1808): Tableau de l'Espagne Moderne. Londres, John Stockdale.

BRANDIS, D. y DEL RÍO, I. (2015): "Paisaje y cultura en la oferta y promoción del turismo en España (1875-1936)", Ería, no 96, pp. 77-96.

BRANDIS, D. (2009): "La imagen cultural y turística de las Ciudades Españolas Patrimonio de la Humanidad", en Ciudades Patrimonio de la Humanidad: Patrimonio, Turismo y Recuperación Urbana. Sevilla, Universidad Internacional de Andalucía y Junta de Andalucía, pp. 72-99.

BRITTON, S. (1990): "Tourism, capital, and place: towards a critical geography of tourism”, Environmental and Planning D: Society and Space, vol. 9 (4), pp. 451-478.

BUCK, R. (1977): "The Ubiquitous Tourist Brochure: Explorations in its Intended and Unintended Uses”, Annals of Tourism Research, vol. 4 (4), pp. 195-207. 
CALATRAVA EXCOBAR, J. (2018): "Turismo de masas y banalización de la historia: Granada y la Alhambra como caso de estudio", en Jornadas La Ciudad del Turismo: apropiaciones estéticas y patrimoniales contemporáneas. Alcalá de Henares, Universidad de Alcalá.

CAMPRUBÍ SUBIRANA, R. (2011): "El rol del turista en la formación de la imagen turística emitida", en Manual de comunicación turística: de la información a la persuasión, de la promoción a la emoción. Gerona, Documenta Universitaria.

CAMPRUBÍ, R., GUIA, J. y COMAS, J. (2009): "La formación de la imagen turística inducida: un modelo conceptual", PASOS. Revista de Turismo y Patrimonio Cultural, vol.7 (2), pp. 255-270.

CARRÈRE LARA, E. (2001): "La imagen desértica de Andalucía a través de los relatos de los viajeros románticos franceses: ¿mito o realidad?”, Cuadernos de Ilustración y Romanticismo, $\mathrm{n}^{\circ}$ 9, pp. 29-46.

CASTRILLO ROMÓN, M.A. y TREMIÑO SAN EMETERIO, C. (1998): “Territorio y patrimonio en la IX Conferencia del Consejo Académico Iberoamericano: ideas y experiencias para una nueva cultura disciplinar", Ciudades: Revista del Instituto Universitario de Urbanística de la Universidad de Valladolid, $\mathrm{n}^{\circ}$ 4, pp. 13-29.

CASTRO GABRIEL, L.P.M. y RODRIGUES SOARES, J.R. (2017): "El uso de la imagen turística en la promoción de los destinos patrimoniales", Tourism and Hospitality International Journal, vol. 8 (2), pp. 51-67.

CENTRO DE DOCUMENTACIÓN DE LA CONSEJERÍA DE TURISMO, COMERCIO Y DEPORTE (2007): La promoción turística vista desde la administración: marketing y campañas de publicidad del turismo en Andalucía. Sevilla, Servicio de Información, Documentación, Estudios y Publicaciones de la Junta de Andalucía.

CHAVES MARTÍN, M.Á. (2012): "El viaje y sus relatos. Una aproximación a la construcción de la imagen de la ciudad histórica", ICONO 14, vol. 10 (2), pp. 57-83.

CHON, K.S. (1991): “Tourism Destination Image Modification Process: Marketing Implications", Tourism Management, vol. 12 (1), pp. 68-72.

COBOS OSUNA, M.A. (2015): Publicidad turística en España. (Trabajo fin de grado). Málaga, Universidad de Málaga.

COHEN, E. (1979): “A phenomenology of touristexperiences”, Sociology, vol. 13 (2), pp. $179-201$.

CORREYERO RUIZ, B. (2014): La propaganda turística y la política turística española durante el franquismo... cuando el turismo aún no era de masas, en I Jornadas sobre Historia del turismo: El Mediterráneo mucho más que sol y playa (1900-2010). Menorca, Instituto Menorquín de Estudios. http://www.ime.cat/WebEditor/Pagines/ file/Beatriz\%20Correyero.pdf

CROMPTON, J.L. (1979): “An Assessment of the Image of Mexico as a Vacation Destination and the Influence of Geographical Location Upon That Image”, Journal of Travel Research, vol. 17 (4), pp. 18-23.

DANN, G. (1996): "Tourists Images of a Destination: An Alternative Analysis", Journal of Travel and Tourism Marketing, vol. 5 (1-2), pp. 41-55.

DIEKMANN, A. (2018): "Tourism and Heritage: a Dialogue of Deaf-Still not Solved", en Sitcon, Belgrado, pp. 3-7. 
DILLEY, R.S. (1986): “Tourist Brochures and Tourist Images”, The Canadian Geographer, vol. 30 (1), pp. 59-65.

DONAIRE BENITO, J.A. y GALÍ ESPELT, N. (2011): "La imagen turística de Barcelona en la comunidad de Flickr", Cuadernos de Turismo, n 27, pp. 291-303.

DOWLING, G.R. (1986): "Managing your corporate images", Industrial Marketing Management, vol. 15 (2), pp. 109-115.m

ECHTNER, C.M. y RITCHIE, B. (1991): “The Meaning and Measurement of Destination Image", The Journal of Tourism Studies, vol. 2 (2), pp. 2-12.

ECHTNER, C.M. y RITCHIE, B. (1993): "The Measurement of Destination Image: An Empirical Assessment", Journal of Travel Research, vol. 31 (4), pp. 3-13.

EDELHEIM, J.R. (2007): "Hidden messages: a polysemic reading of tourist brochures", Journal of Vacation Marketing, vol. 13 (1), pp. 5-17.

ERDMAN, D.V., LUNDMAN, P., DENDLE, B.J., MOLLENAUER, R.R, PALLOTTA, A. y PATTY, J.S. (1996): The Romantic Movement: A Selective and Critical Bibliography for 1995. Cornualles, Locust Hill Press.

FERIA TORIBIO, J.M. (2010): "Patrimonio territorial y desarrollo sostenible: un estudio comparativo en Iberoamérica y España”, Estudios Geográficos, n 268, pp. 129-159.

FERIA TORIBIO, J.M. (2013): "El patrimonio territorial: algunas aportaciones para su entendimiento y puesta en valor", erph_Revista Eletrónica de Patrimonio Histórico, $\mathrm{n}^{\mathrm{o}} 12$, pp. 1-25.

FERNÁNDEZ CACHO, S., FERNÁNDEZ SALINAS, V., HERNÁNDEZ LEÓN, E., LÓPEZ MARTÍN, E., QUINTERO MORÓN, V., RODRIGO CÁMARA, J.M. y ZARZA BALLUGUERA, D. (2010): Paisajes y patrimonio cultural en Andalucía. Tiempo, usos e imágenes. Sevilla, Instituto Andaluz del Patrimonio Histórico, Consejería de Cultura, Junta de Andalucía.

FERNÁNDEZ LACOMBA, J. (Comp.) (2007): Los Paisajes andaluces: Hitos y miradas en los siglos XIX y XX. Sevilla, Consejería de Cultura, Junta de Andalucía.

FERRER-ROSELL, B. y MARINE-ROIG, E. (2020): "Projected versus perceiveddestinationimage", Tourism Analysis, vol. 25 (2-3), pp. 227-237.

FODOR (1952): Spain and Portugal in 1952. Nueva York, Fodor Travel Publications.

FRANCESCUTTI, P. (2016): "Una España deportiva, más diversa y sin toreros: análisis de los recientes anuncios de promoción turística", ARI, n ${ }^{\circ} 76,21$ de octubre de 2013 , pp. 1-13.

FRANCO RUBIO, G. (2010): "El viaje como laboratorio intercultural. Viajeros británicos y españoles en el siglo XVIII", Tiempos Modernos, $\mathrm{n}^{\circ}$ 21, pp. 1-35.

FREIXA LOBERA, C. (1991): La imagen de España en los viajeros británicos del siglo XVIII. (Tesis doctoral).Barcelona, Departamento de Geografía, Universidad de Barcelona.

FRIAS, D.M., RODRIGUEZ, J. y CASTAÑEDA, A. (2008): “Internet vs. Travel Agencies on Pre-visit Destination Image Formation: An Information Processing View"; Tourism Management, vol. 29 (1), pp. 163-179.

FUENTES LUQUE, A. (2005): "La traducción de promoción turística institucional: la proyección de la imagen de España”, en La traducción en el sector turístico. Granada, Atrio, pp.59-92. 
FUERTES-MANJÓN, R. (2004): “El viaje del Mayor W. Dalrymple por tierras leonesas: una visión ilustrada del mundo maragato”, Argutorio, n 14, pp. 51-54.

GALANT, I. (2018): Hitos patrimoniales sevillanos: permanencias y novedades en el sector turístico, en Jornadas La Ciudad del Turismo: apropiaciones estéticas y patrimoniales contemporáneas. Alcalá de Henares, Universidad de Alcalá.

GALÍ ESPELT, N. y DONAIRE BENITO, J.A. (2005): "The social construction of the image of Girona: the methodological approach", Tourism Mangement, vol. 26 (5), pp. 777-785.

GALÍ ESPELT, N. y DONAIRE BENITO, J.A. (2006): "La imagen percibida por los turistas de la ciudad de Girona”, Estudios Turísticos, n 168, pp. 123-139.

GAMERO ALIAGA, M. (2007): "La contemplación del mundo en la sociedad contemporánea en base a la construcción de imaginarios sociales", Tonos digital: Revista de estudios filológicos, $\mathrm{n}^{\circ} 14$.

GARAYO URRUELA, J.M. (2001): "Los espacios naturales protegidos: entre la conservación y el desarrollo", Lurralde. Investigación y Espacio, n 24, pp. 271-293.

GARCÍA GOMEZ, F. (1995): "Descubriendo la ciudad (I). El urbanismo malagueño según los viajeros extranjeros del siglo XIX”, Baética. Estudios de Arte, Geografía e Historia, ${ }^{\circ} 17$, pp. 7-29.

GARCÍA MERCADAL, J. (1999): Viajes de extranjeros por España y Portugal: desde los tiempos más remotos hasta comienzos del siglo XX. Valladolid, Consejería de Educación y Cultura, Junta de Castilla y León.

GARCÍA QUEVEDO, K.M. y MERCADO LÓPEZ, E. (2019): “De reflexión a propuesta metodológica sobre la imagen de territorios turísticos y su patrimonio. La Ruta de Don Vasco", Journal of Tourism and Heritage Research, vol. 2 (1), pp . 260-272.

GARRIDO, M. (2005): "La publicidad turística en Andalucía (2002-2005): Andalucía sólo hay una. La tuya vs. Andalucía te quiere", Questiones Publicitarias, Revista Internacional de Comunicación y Publicidad, vol.1 (10), pp. 77-97.

GARTNER, C.W. (1994): "Image formation process", Journal of Travel y Tourism Marketing, vol. 2 (2), pp. 191-216.

GARTNER, W. C. y HUNT, J. D. (1987): “An analysis of state image change over a twelve-year period (1971- 1983)”, Journal of Travel Research, vol. 26 (2), pp. 15-19.

GARTNER, W.C. (1993): "Image Formation Process", Journal of Travel y Tourism Marketing, vol. 2 (2-3), pp. 191-216.

GOODRICH, J.N. (1978): "The Relationship Between Preferences for and Perceptions of Vacation Destinations: Application of a Choice Model", Journal of Travel Research, vol. 17 (2), pp. 8-13.

GUERRERO, A.C. (1990): Viajeros británicos en la España del siglo XVIII. Madrid, Aguilar.

GUNN, C. (1988): Vacationscape: Designing Tourist Regions. Nueva York, V.N. Reinhold. HALL, S. (1997): Representation: Cultural Representations and Signifying Practices. Londres, Sage.

HÉRAN, F. (1979): "L'invention de l'Andalousie au XIXe S. dans la littérature de voyage. Origine et fonction sociales de quelques images touristiques", en Tourisme et développementrégional en Andalousie. París, Éditions E. de Broccard, p. 29. 
HERNÁNDEZ RAMÍREZ, J. (2007): "La parte por el todo. Imágenes de Andalucía emitidas por organismos públicos", en La imagen de Andalucía en el discurso turístico. Sevilla, Factoría de Ideas, Centro de Estudios Andaluces.

HERNÁNDEZ RAMÍREZ, J. (2008): La imagen de Andalucía en el Turismo. Sevilla, Fundación Centro de Estudios Andaluces, Consejería de la Presidencia, Junta de Andalucía.

HIERNAUX, D. (2002): “Turismo e imaginarios", Cuaderno de Ciencias Sociales, no 123, pp. 7-36.

HUNG, J.Y., LIN, F.L., YANG, W.G., y LU, K.S. (2012): “Construct the destination image formation model of Macao: the case of Taiwan tourists to Macao", Tourism and Hospitality Management, vol. 18 (1), pp. 19-35.

INE (2019a): Encuesta de Ocupación Hotelera diciembre 2019. Madrid.

INE (2019b): Encuesta de Movimientos Turísticos en Frontera diciembre 2019. Madrid.

INE (2019c): Encuesta de Gasto Turístico diciembre 2019. Madrid.

KIM, H. y RICHARDSON, S.L. (2003): "Motion Picture ImpactsonDestinationImages", Annals of Tourism Research, vol. 30, $\mathrm{n}^{\mathrm{o}}$ 1, pp. 216-237

LAGUNAS, D. (2005): "Turismo, espacio y representación del patrimonio en el sistema mundial", en El encuentro del turismo con el patrimonio cultural: concepciones teóricas y modelos de aplicación. Sevilla, Federación de Asociaciones de Antropología del Estado Español y ASANA, pp. 147-167.

LASSO DE LA VEGA, C. (2006): La imagen de Andalucía en el discurso publicitario. Sevilla, Centro de Estudios Andaluces, Consejería de la Presidencia.

LERIVRAY, B. (1975): Guides bleus, guides vertes et lunettes roses. París, Du Chef.

LLEÓ CAÑAL, V. (1984): "España y los viajeros románticos", Estudios Turísticos, no 83, pp. 45-53.

LOIS GONZÁLEZ, R.C. (2018): Planificación y gestión territorial del turismo, en Teorías, modelos y destinos turísticos en épocas de cambios. XVI Coloquio de Geografía del Turismo, el Ocio y la Recreación de la AGE. León.

LÓPEZ ONTIVEROS, A. (1988): "El paisaje de Andalucía a través de los viajeros románticos: creación y pervivencia del mito andaluz desde una perspectiva geográfica", en Viajeros y Paisajes. Madrid, Alianza Editorial, pp. 31-65.

LÓPEZ ONTIVEROS, A. (2001): “Caracterización geográfica de Andalucía según la literatura viajera de los XVIII y XIX”, Eria, no 54-55, pp. 7-51.

LÓPEZ-BURGOS DEL BARRIO, M.A. (2010): Viaje $2^{\circ}$. Los primeros viajeros por Andalucía. Sevilla, Biblioteca Virtual de Andalucía, Consejería de Cultura, Junta de Andalucía.

MADERUELO, J. (2006): Paisaje y Pensamiento. Madrid, Abada.

MARKWICK, M. (2001): "Postcards from Malta Image, Consumption, Context", Annals of Tourism Research, vol. 28 (2), pp. 417-438.

MARTÍN DE LA ROSA, B. (2003): "La imagen turística de las regiones insulares: las islas como paraísos", Cuadernos de Turismo, no 11 , pp. 127-137.

MARTÍNEZ, E. y NICOLÁS, M.Á. (2014): “The Construction of Tourist Space by Public Administration and Institutional Communication: The Image of the Band Andalucía as a Tourist Destination”, Journal of Promotion Management, vol. 20 (2), pp. 181-199. 
MATTEUCCI, X. y ÖNDER, I. (2018): "Using drawings to explore images of Vienna", Tourism Analysis, vol. 23(4), pp. 517-531.

MCDONALD, J. (2015): The Role of Ethics on Tourist Destination Image Formation: An Analysis of the French Student Travel Market. Sofía, Business administration. Université Nice Sophia Antipolis.

MEHMOOD, S., LIANG, C. y GU, D. (2018): "Heritage Image and Attitudes toward a Heritage Site: Do They Really Mediate the Relationship between User-Generated Content and Travel Intentions toward a Heritage Site?", Sustainability, vol. 10 (12), p. 4.403.

MÉNDEZ BAIGES, M. (2017): "El estilo del relax y la imagen pop de la Costa del Sol", en Immaginare il Mediterraneo. Nápoles, ArtstudioPaparo, pp.101-110.

MILMAN, A. y PIZAM, A. (1995): "The Role of Awareness and Familiarity with a Destination: The Central Florida Case", Journal of Travel Research, vol. 33 (3), pp. 21-27.

MILMAN, A. (2011): "The symbolic role of postcards in representing a destination image: the case of Alanya, Turkey", International Journal of Hospitality y Tourism Administration, vol. 12 (2), pp. 144-173.

MINISTERIO DE CULTURA Y DEPORTE (2019): Base de datos de Bienes Inmuebles. Madrid.

MINISTERIO PARA LA TRANSICIÓN ECOLÓGICA (2019): Banco de Datos de la Naturaleza. Madrid.

MORENO, S.G., BEERLI, A. P. y DE LEÓN, J.L. (2012): “Entender la imagen de un destino turístico: factores que la integran y la influencia de las motivaciones", Criterio Libre, $\mathrm{n}^{\circ}$ 16, pp. 115-142.

MORGAN, N. y PRITCHARD, A. (2001): Advertising in Tourism and Leisure. Oxford, Butterworth-Heinemann.

MULERO MENDIGORRI, A. (2015): "Hacia la gestión integrada del patrimonio en clave territorial: un análisis crítico a partir de la experiencia andaluza", Investigaciones Geográficas, $\mathrm{n}^{\circ}$ 63, pp. 69-84.

NAVAGERO, A. (1983): Viaje por España, 1524-1526, Volumen 1. Londres, Turner.

NELSON, V. (2005): "Representation and images of people, place and nature in Grenada's tourism”, Gografiska Annaler: Series B, Human Geography, vol. 87 (2), pp. 131-143. NOVO ESPINOSA DE LOS MONTEROS, G., OSORIO GARCÍA, M., TORRES NAFARRATE, J. y ESQUIVEL SOLÍS, E. (2013): "Viajes, actuantes, escenarios e interacciones: un análisis de la publicidad de los destinos, a partir de sus semánticas visuales", Investigaciones Turísticas, $\mathrm{n}^{\mathrm{o}}$ 6, pp. 27-46.

NOYA, J. (2002): La imagen de España en el exterior, Estado de la cuestión. Madrid, Real Instituto Elcano de Estudios Internacionales y Estratégicos.

ORTEGA VALCÁRCEL, J. (1998): "Patrimonio territorial: el territorio como recurso cultural y económico", Ciudades: Revista del Instituto Universitario de Urbanística de la Universidad de Valladolid, $\mathrm{n}^{\circ}$ 4, pp. 33-48.

PACK, S.D. (2008): “Tourism, Modernization, and Difference: A Twentieth-Century Spanish Paradigm", Sport in Society, vol. 11 (6), pp. 657-672.

PEARCE, D. (1989): Tourist Development. Nueva York, Longman. 
PERELLÓ, J.L. (2006): La imagen del destino turístico en el proceso global de satisfacción del consumidor: Metodología para su estudio. La Habana, ETUR.

PICAZO, P. y MORENO-GIL, S. (2017): “Analysis of the projected image of tourism destinations on photographs: A literature review to prepare for the future", Journal of Vacation Marketing, vol. 25 (1), pp. 3-24.

PICÓN PRADO, E., VARELA MALLOU, J., RIAL BOUBETA, A. y BRAÑA TOBÍO, T. (2013): "Habi: una herramienta para la representación de la imagen de un producto o servicio", Revista Española de Investigación de Marketing ESIC, vol. 17 (1), pp. 83-104.

PRATS CANALS, L. (2006): "La mercantilización del patrimonio: entre la economía turística y las representaciones identitarias", PH Boletín del Instituto Andaluz del Patrimonio Histórico, $\mathrm{n}^{\circ}$ 58, pp. 72-80.

PRITCHARD, A. y MORGAN, N.J. (2001): "Culture, identity and tourism representation: marketing Cymru or Wales?", Tourism Management, vol. 22 (2), pp. 167-179.

PUCHE RUIZ, M.C. (2014): “Cine y turistas en la Andalucía previa al 'boom' de masas: Así los veíamos, así nos veían”, en VII Jornadas de Investigación en Turismo: Cultura, desarrollo y nuevas tecnologías. Sevilla, Universidad de Sevilla, pp. 289-315.

PUCHE RUIZ, M.C. (2019): Imagen e identidad territorial. El cine como instrumento de análisis del turismo en Andalucía (1905-1975). (Tesis Doctoral). Sevilla, Departamento de Geografía Física y Análisis Geográfico Regional, Universidad de Sevilla.

REYNOLDS, W.H. (1965): "The role of the consumer in image building", California Management Review, vol. 7 (3), pp. 69-76.

RICHARDSON, S. y CROMPTON, J.L. (1988): “Cultural variations in perceptions of vacation attributes", Tourism Management, vol. 9 (2), pp. 128-136.

RIVERA BLANCO, J. (2014): "El sueño de un visionario", en Visite España: la memoria rescatada. Madrid, Biblioteca Nacional, pp. 148-159.

RODRÍGUEZ DARIAS, A.J., DÍAZ RODRÍGUEZ, P. y SANTANA TALAVERA, A. (2012): "Estrategias de gestión de imagen de destino en Fuerteventura. De los folletos a la intercomunicación”, Cuadernos de Turismo, no 30, pp.219-239.

RODRÍGUEZ MARTÍNEZ, F. (2000): El paisaje de España y Andalucía en los viajeros románticos. El mito andaluz en la perspectiva geográfica actual. Disponible en hispano.cervantes.es/documentos/rodriguez.pdf

SAN MARTÍN GUITIÉRREZ, H. y RODRÍGUEZ DEL BOSQUE, I.A. (2008): "Exploring the cognitive-affective nature of destination image and the role of psychological factors in its formation", Tourism Management, vol. 29 (2), pp. 263-277.

SAN MARTÍN GUITIÉRREZ, H., RODRÍGUEZ DEL BOSQUE, I.A. y VÁZQUEZ CASIELLES, R. (2006): “Análisis de la imagen en turismo mediante técnicas estructuradas y no estructuradas: implicaciones competitivas para los destinos turísticos", Revista Asturiana de Economía, $\mathrm{n}^{\circ}$ 35, pp. 69-91.

SAN MARTÍN GUTIÉRREZ, H. (2005): Estudio de la imagen de destino turístico y el proceso global de satisfacción: adopción de un enfoque integrador. (Tesis doctoral). Santander, Departamento de Administración de Empresas, Universidad de Cantabria.

SAN MARTÍN GUTIÉRREZ, H., RODRÍGUEZ DEL BOSQUE RODRÍGUEZ, I.A. y VÁZQUEZ CASIELLES, R. (2006): “Análisis de la imagen en turismo mediante 
técnicas estructuradas y no estructuradas: implicaciones competitivas para los destinos turísticos", Revista Asturiana de Economía, n 35, pp. 69-91.

SANTANA TALAVERA, A., DÍAZ RODRÍGUEZ, P. y RODRÍGUEZ DARIAS, A.J. (2011): "Renovación de destinos y percepción de la protección ambiental. El caso de Fuerteventura (Islas Canarias, España)”, Investigaciones Turísticas, n ${ }^{\circ}$ 1, pp. 1-20.

SANTOS SOLLA, X.M. (2008): "Paisaje e identidad en la promoción de la imagen de los destinos turísticos", en Espacios Turísticos: mercantilización, paisaje e identidad. Alicante, Universidad de Alicante, pp. 195-206.

SINGH, N. y LEE, M.J. (2009): "Convergence and congruency of pictorial destination images in DMOs' websites and brochures”, Journal of Hospitality Marketing y Management, vol. 18 (8), pp. 845-858.

SOLER, E. (2013): Imagen de la moderna España. Alicante, Publicaciones de la Universidad de Alicante.

TAPACHAI, N. y WARYSZAK, R. (2000): “An Examination of the Role of Beneficial Image in Tourist Destination Selection”, Journal of Travel Research, vol. 39 (1), pp. 37-44.

THUROT, J. y THUROT, G. (1983): “The Ideology of Class and Tourism: Confronting the Discourse of Advertising”, Annals of Tourism Research, vol.10 (1), pp.173-189.

TORRES CAMACHO, J. (2017): "Los premios de embellecimiento: paisaje e identidad turística local”, en XXV Congreso de Geógrafos Españoles: Naturaleza, territorio y cultural en un mundo global. Madrid.

TRAVERSO CORTÉS, J. y ROMÁN ONSALO, M. (2009): "Formulación de la Imagen de un Destino Turístico, propuesta de un Modelo de Gestión”, en II Jornadas de Investigación en Turismo. Sevilla, Universidad de Sevilla, pp. 515-540.

TRAVERSO CORTÉS, J. (2007): "Modelo para la obtención de la imagen de un destino turístico", Estudios Turísticos, no 174, pp. 33-48.

TROITIÑO VINUESA, M.Á. y TROITIÑO TORRALBA, L. (2011): “Estudio sobre la funcionalidad turística del patrimonio cultural del municipio de Carmona y estrategias de actuación”, PH Boletín del Instituto Andaluz del Patrimonio Histórico, n ${ }^{\circ}$ 78, pp. 4-13.

TROITIÑO VINUESA, M.Á. y TROITIÑO TORRALBA, L. (2015): “Territorio y Sistemas Patrimoniales: la Región Urbana de Madrid”, Ciudad y Territorio: Estudios Territoriales, $\mathrm{n}^{\circ} 184$, pp. 255-273.

TROITIÑO VINUESA, M.Á. (1998): "Patrimonio arquitectónico, cultura y territorio", Ciudades: Revista del Instituto Universitario de Urbanística de la Universidad de Valladolid, $\mathrm{n}^{\mathrm{O}}$ 4, pp. 95-104

TROITIÑO VINUESA, M.Á. (2000): “Ordenación del Territorio y Desarrollo Territorial: La Construcción de las Geografías del Futuro", en Lecturas Geográficas: homenaje a José Estébanez Álvarez. Madrid, Universidad Complutense de Madrid, vol. 1, pp. 629-642.

TROITIÑO VINUESA, M.Á. (2011): “Territorio, patrimonio y paisaje: desafíos de una ordenación y gestión inteligentes”, Ciudad y Territorio: Estudios Territoriales, no 169 170, pp. 561-569. 
TRONCOSO, C.A. (2013): "Política turística y patrimonial en la ciudad de Salta, Argentina. Disonancias en la protección y usos del centro histórico", Estudios y perspectivas en turismo, vol. 22 (6), pp. 1.002-1.024.

UM, S. y CROMPTON, J.L. (1990): “Attitude Determinants in Tourism Destination Choice”, Annals of Tourism Research, vol. 17 (3), pp. 432-448.

URRY, J. (1990): The tourist gaze. Londres, Sage.

URRY, J. (1996) "How societies rernember the past", en Theorizing Museums, Sociological Review Monographs and Blackwells. Oxford, pp. 45-65.

URRY, J. (2002): The Tourist Gaze: Leisure and Travel in Contemporary Societies. Londres, Sage.

VERDÚ, V. (2005): "El espectáculo de las grandes marcas", en Foro de las Marcas Renombradas Españolas. Madrid.

WILLIAMSON, H.W.S. (1951): The Tourist Guide-Book of Spain. Londres, The Times of Spain.

WOODSIDE, A.G. y LYSONSKI, S. (1989): “A General Model of Traveler Destination Choice", Journal of Travel Research, vol. 27 (4), pp. 8-14.

ZAPATA VÁZQUEZ, M. (2018): "Paisaje turístico: mercancía y estereotipo de la experiencia y su imagen", International Journal of World of Tourism, vol. 5 (10), pp. 1-14. 